\title{
Preparation of 1,6-di-deoxy-D-galacto and 1,6-di-deoxy-L-altro nojirimycin derivatives by aminocyclization of a 1,5-dicarbonyl derivative
}

\author{
Doretta Cuffaro, Martina Landi, Felicia D'Andrea, ${ }^{*}$ Lorenzo Guazzelli ${ }^{\star}$ \\ Dipartimento di Farmacia, Università di Pisa, Via Bonanno 6/33, 56126, Pisa, Italy \\ *email: lorenzo.guazzelli@unipi.it, felicia.dandrea@unipi.it
}

\begin{abstract}
Iminosugars are known glycosidase inhibitors which are the subject of drug development efforts against several diseases. The access to structurally-related families of iminosugars is of primary importance for running structure-activity relationship studies. In this work, the double reductive amination (aminocyclization) reaction of a dicarbonyl derivative of the Larabino series, in turn obtained from lactose, is reported. Different ratios of 1,6-di-deoxy-Dgalacto and 1,6-di-deoxy-L-altro nojirimycin derivatives were obtained depending on the amine employed in this transformation which provided an insight into the effects of their structure on the outcome of the reaction. Of particular interest were the results obtained when two enantiomeric amino acids (D-Phe-OMe and L-Phe-OMe) were used, which resulted in the inversion of the reaction stereoselectivity.
\end{abstract}

\section{Introduction}

Carbohydrates play key roles in almost every major biological event and are receiving increasing attention both for elucidating the interaction of cells with their surroundings and as potential drug targets [1-8]. Carbohydrate mimics represent intriguing structural variation of the naturally occurring sugar glycan structures. Within this class fall iminosugars, also known as azasugars, where the endocyclic oxygen is replaced by a basic nitrogen atom [9]. This apparently simple modification confers to these structures significant biological activities. Indeed, iminosugars are known as inhibitors of glycosidases which are enzymes responsible for the hydrolysis of the glycosidic bonds in biologically relevant processes such as intestinal digestion, post-translational processing of the sugar chain of glycoproteins and lysosomal catabolism of glycoconjugates [10]. Iminosugars are a class of structurally diverse molecules (polyhydroxylated piperidines and pyrrolidines and their derivatives) which have been investigated as antiviral agents (against HIV-1, herpes simplex virus, bovine viral diarrhoea virus (BVDV), and hepatitis C 
virus $(\mathrm{HCV}))$, as antidiabetics, in the treatment of lysosomal storage disorders such as Gaucher's and Niemann Pick type C, in immune modulation and as anticancer agents [11]. In the last 50 years, a great number of compounds have been synthesized and tested against different biological targets, while only few glycosidase inhibitors have been progressed to clinical trials [12]. Their structures are closely related to 1-deoxy-Dnojirimycin (DNJ) and nowadays the following compounds are available on the market: the Acarbose DNJ analogue Miglitol or Glyset [13-15], the carbamino sugar Voglibose [16] (used in the treatment of diabetes type II), Miglustat or Zavesca [17] for the treatment of Gaucher's disease and the antiviral drug Tamiflu or Oseltamivir [18] (Figure1).

Usually, the main limitation associated with the use of iminosugars is the lack of adequate selectivity, which results into detrimental side effects associated to their therapeutic application. In order to improve the binding affinity between substrate and domain, some efforts in the design and synthesis of new selective iminosugars have been carried out. [19-21]

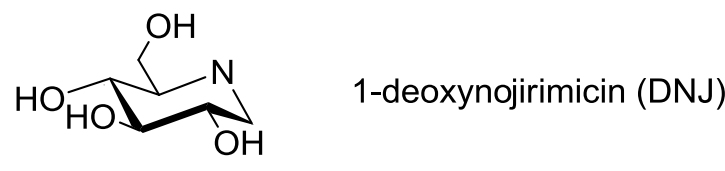

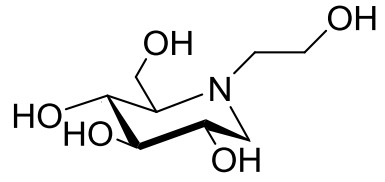

Miglitol or Glyset

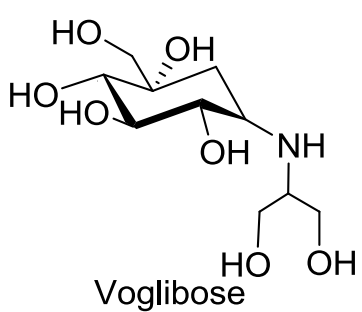

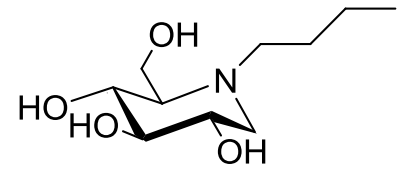

Miglustat or Zavesca

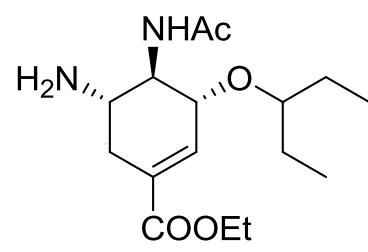

Oseltamivir or Tamiflu

Figure 1. Chemical structure of glycosidase inhibitors.

The synthesis of iminosugar derivatives is quite complex due to the polar nature and stereochemical complexity of the target structures [22]. Different approaches have been explored in the past years to address this challenge. Some works reported the syntheses of 1-deoxynojirimycin and its isomers employing as starting materials substrates from the chiral pool such as carbohydrates [23-25] or amino acids [26, 27]. Other strategies started 
instead from different open chain precursors and were based on chemoenzymatic [28, 29] or asymmetric reactions such as dihydroxylation [30], aldol reaction coupled with a reductive amination [31] or aminohydroxylation [32] transformations.

As part of an ongoing project aimed at converting lactose into valuable compounds [33, 34] by means of dicarbonyl intermediates [35-37], we report here the intramolecular double reductive amination (aminocyclization) reaction of a partially protected 6-deoxy-L-arabinohexos-5-ulose to access 1,6-dideoxy-D-galacto and 1,6-dideoxy-L-altro nojirimycin derivatives. The influence of the amines' steric hindrance and of the stereochemistry of two enantiomeric amino acids, all employed as reagents, was evaluated with a particular emphasis on the aminocyclization reaction outcome.

\section{Results and discussion}

The synthetic pathway started with the synthesis of the 2-O-benzyl-6-deoxy-L-arabinohexos-5-ulose 5 as the key intermediate (Scheme 1). Dicarbonyl derivative 5 was prepared from the previously reported enol ether 1 [38] which in turn can be obtained from lactose on a multi gram scale. By applying the original protocol of Mioskovski [39] enol ether 1 was converted into a complex mixture of derivatives (2-4, $80 \%$ overall yield) due to the instability of the isopropylidene protecting groups under these conditions $\left(\mathrm{PPh}_{3} \mathrm{HBr}\right.$, $\mathrm{MeOH})$.

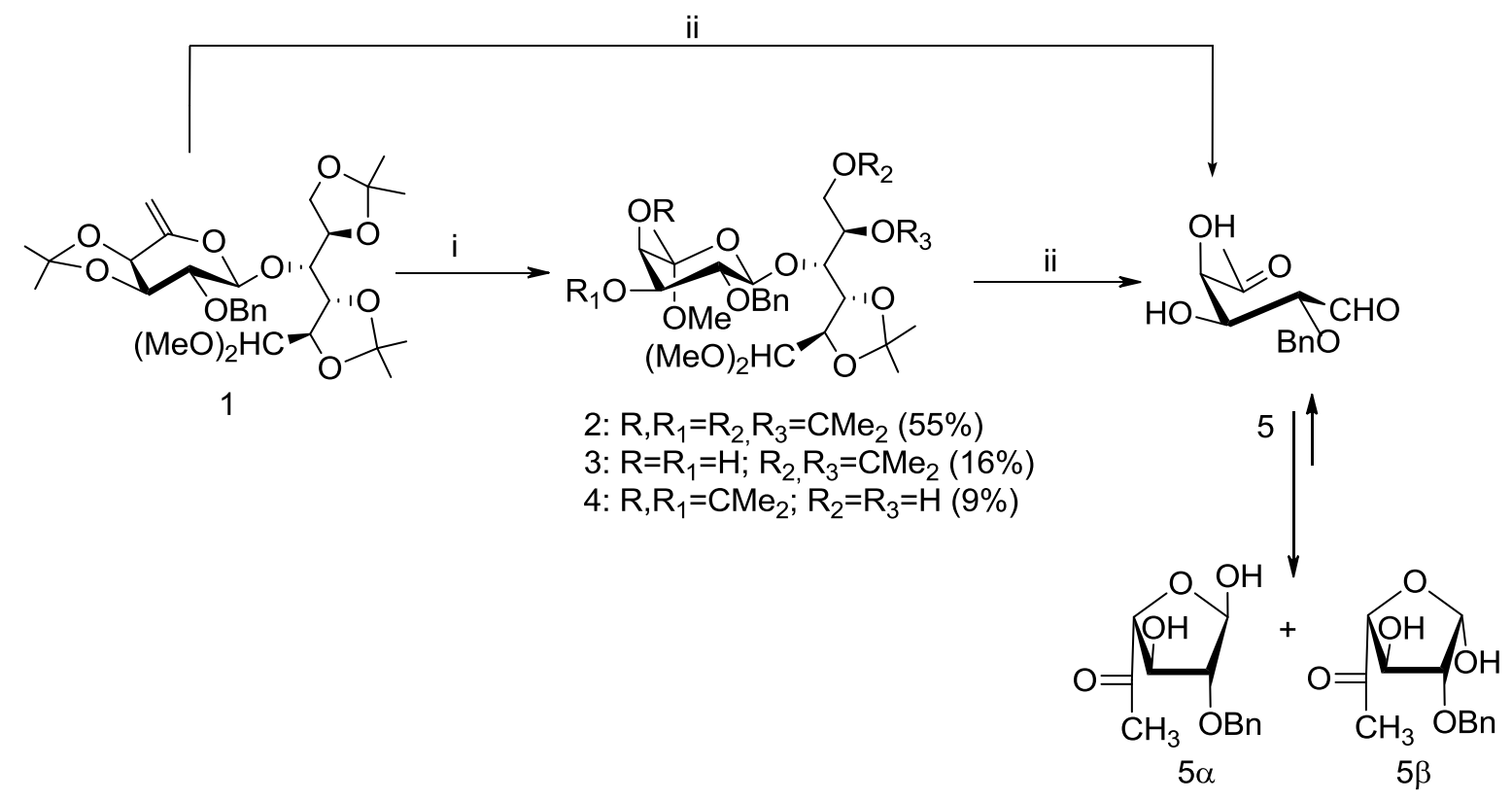

Scheme 1. Reagents and conditions: (i) $\mathrm{PPh}_{3} \mathrm{HBr}, \mathrm{MeOH}, 0.5 \mathrm{~h}$, rt; (ii) $\mathrm{CF}_{3} \mathrm{COOH}, 4: 1$ $\mathrm{CH}_{3} \mathrm{CN}-\mathrm{H}_{2} \mathrm{O}, 18 \mathrm{~h}$, r.t. (yield of $5: 76 \%$ from the crude mixture of 2,3 and $4 ; 85 \%$ from 1 ). 
The following treatment of the mixture of 1,5-bis-glycosides 2-4 with trifluoroacetic acid caused the hydrolysis of all the acetal groups thus affording the desired compound in a satisfactory yield $(\mathbf{5}, 76 \%)$. It is worth mentioning that it was also possible to prepare $\mathbf{5}$, even in a higher yield (85\%), by adding trifluoroacetic acid directly to 1 (Scheme 1). As expected, 1,5-dicarbonyl intermediate 5 was obtained as a mixture of furanose forms $5 \alpha$ and $\mathbf{5} \boldsymbol{\beta}$ (ca $4: 1$ ratio) as assessed by NMR. In the proton spectrum, the presence of only two doublet signals at $\delta 5.41\left(J_{1,2}=1.1 \mathrm{~Hz}\right)$ and $\delta 5.43\left(J_{1,2}=3.9 \mathrm{~Hz}\right)$, related to anomeric protons, confirmed the almost exclusive presence of furanose tautomers. The low values of these coupling constants as well as of $J_{2,3}(2.2$ and $5.0 \mathrm{~Hz})$ strongly suggest the absence of pyranose tautomers. The observed composition is in good agreement with the tautomeric equilibrium previously reported for other aldohexos-5-ulose derivatives, where the furanose forms are the prevalent species provided that the $4-\mathrm{OH}$ is free to engage in the emiacetalization process [36].

Derivative $\mathbf{5}$ was reacted with quaternary ammonium salts characterized by an increasing substitution around the nitrogen $\left(-\mathrm{H},-\mathrm{OH},-\mathrm{CH}_{3}, \mathrm{CH}_{2} \mathrm{Ph},-\mathrm{CH}(\mathrm{Ph})_{2}\right)$, and with selected amino acids (Gly, D-Phe, L-Phe) protected as methyl esters (Scheme 2). The reaction was performed following a protocol previously reported by us $\left(\mathrm{NaBH}_{3} \mathrm{CN}, \mathrm{MeOH}, 60^{\circ} \mathrm{C}\right)$ [38]. Azasugars 6a-h and 7a-h were isolated in satisfactory overall yields (Table 1) after chromatographic purification, and their structures and stereochemistries were established by NMR analysis. In particular, the known effects caused by the nitrogen atom on the chemical shifts of vicinal protons $(\mathrm{H}-1 \mathrm{ax}, \mathrm{H}-1$ eq and $\mathrm{H}-5)$, which give resonance signals at higher fields ( $\delta 1.80-3.40$, see experimental section) than those in alpha to the oxygen atom, and the related $J_{1,2}$ and $J_{4,5}$ coupling constants allowed for the identification of the C5 epimers $6 \mathbf{a}-\mathbf{h}$ and $\mathbf{7 a}-\mathbf{h}$. In addition, in the case of ${ }^{13} \mathrm{C}$ spectra again the signals of carbons adjacent to the nitrogen ( $\mathrm{C}-1$ and $\mathrm{C}-5)$, which are shielded and easily recognisable by DEPT experiments, were diagnostics for the $\mathrm{C}-5$ epimers. 


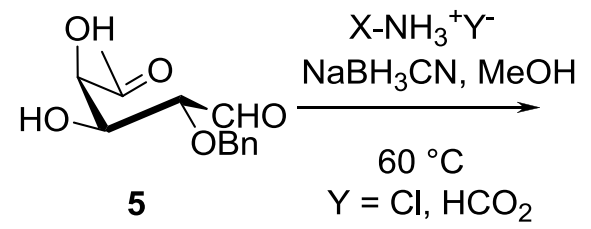

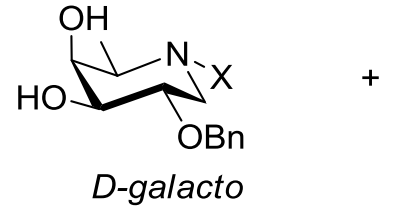

6a: $X=\mathrm{H}$
6b: $X=\mathrm{Me}$
6c: $X=\mathrm{CH}_{2} \mathrm{Ph}$
6d: $\mathrm{X}=\mathrm{CHPh}_{2}$
6e: $\mathrm{X}=\mathrm{OH}$
6f: $\mathrm{X}=\mathrm{CH}_{2} \mathrm{COOMe}$
6g: $\mathrm{X}=(\mathrm{D})-\mathrm{CH}(\mathrm{Bn})$ COOMe
6h: $\mathrm{X}=(\mathrm{L})-\mathrm{CH}(\mathrm{Bn})$ COOMe

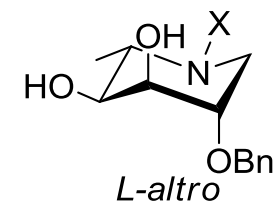

7a: $X=\mathrm{H}$

7b: $\mathrm{X}=\mathrm{Me}$

7c: $\mathrm{X}=\mathrm{CH}_{2} \mathrm{Ph}$

7d: $\mathrm{X}=\mathrm{CHPh}_{2}$

7f: $\mathrm{X}=\mathrm{CH}_{2} \mathrm{COOMe}$

7g: $\mathrm{X}=(\mathrm{D})-\mathrm{CH}(\mathrm{Bn}) \mathrm{COOMe}$

7h: $\mathrm{X}=(\mathrm{L})-\mathrm{CH}(\mathrm{Bn}) \mathrm{COOMe}$

Scheme 2. Intramolecular double reductive amination (aminocyclization) reaction of 5.

Table 1. Yields of isolated products and selectivity of the aminocyclization reaction

\begin{tabular}{|c|c|c|c|}
\hline Entry & Amine & $\begin{array}{c}\text { Products } \\
\text { (Isolated yield) }\end{array}$ & D-galacto/L-altro ratio ${ }^{a}$ \\
\hline 1 & $\mathrm{NH}_{3}$ & $6 a+7 a(68 \%)$ & $75: 25$ \\
\hline 2 & $\mathrm{CH}_{3} \mathrm{NH}_{2}$ & $6 b+7 b(62 \%)$ & $80: 20$ \\
\hline 3 & $\mathrm{PhCH}_{2} \mathrm{NH}_{2}$ & $6 c(40 \%)$ and 7c (16\%) & $70: 30$ \\
\hline 4 & $\mathrm{Ph}_{2} \mathrm{CHNH}_{2}$ & $6 d+7 d(64 \%)$ & $45: 55$ \\
\hline 5 & $\mathrm{NH}_{2}-\mathrm{OH}$ & $6 e(56 \%)$ & 100:0 \\
\hline 6 & Gly-OMe & $6 f(39 \%)$ and $7 f(17 \%)$ & $70: 30$ \\
\hline 7 & D-Phe-OMe & $6 \mathbf{g}(14 \%)$ and $7 \mathbf{g}(49 \%)$ & $25: 75$ \\
\hline 8 & L-Phe-OMe & $6 h+7 h(58 \%)$ & $65: 35$ \\
\hline
\end{tabular}

${ }^{a}$ Ratios were determined by NMR analysis of the crude product.

For $\mathbf{6 c}, \mathbf{7 c}$ and mixture $\mathbf{6 d} / \mathbf{7 d}$ and $\mathbf{6 h} / \mathbf{7 h}$, in order to complete the NMR characterization or to simplify the purification process, an acetylation reaction $\left(\mathrm{Ac}_{2} \mathrm{O} / \mathrm{Py} 1: 2,24 \mathrm{~h}\right.$, Scheme 3$)$ was performed affording products 8-13 in good yields. It is of interest to highlight that it was possible to separate the diastereoisomeric mixture of iminosugars only when $\mathrm{PhCH}_{2} \mathrm{NH}_{2}$, Gly-OMe or D-Phe-OMe was used as reacting partner (entries 3, 6, 7, Table 1). 


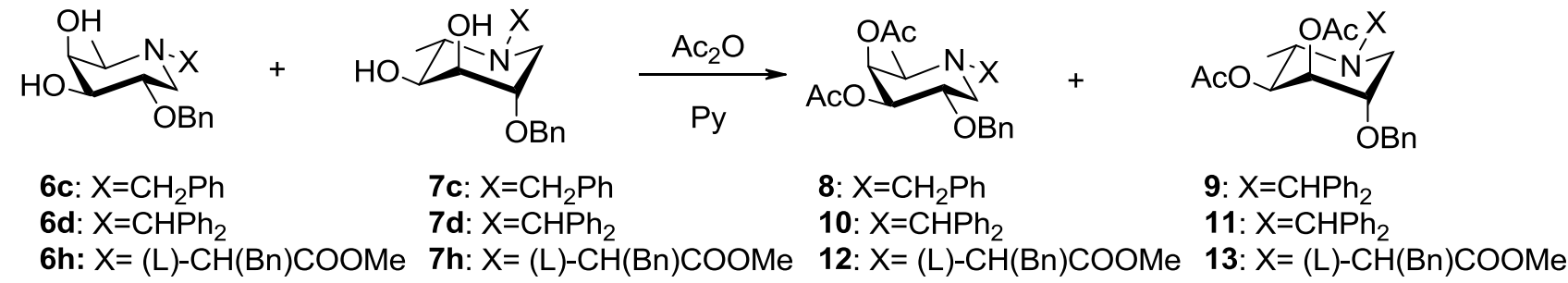

Scheme 3. Acetylation of iminosugars $6 c / 7 c, 6 d / 7 d$ and $6 \mathrm{~h} / 7 \mathrm{~h}$.

The stereoselectivity of the aminocyclization reaction of aldohexos-5-uloses is commonly accepted to be governed by the direction of hydride attack on a cyclic iminium ion intermediate. The latter is formed through two consecutive steps: the condensation of the amino group with the more reactive aldehyde function followed by a second amination on the C-5 keto group. Stereoelectronic effects (preferential axial attack of the hydride) as well as conformational effects (stability of the half chair conformers) can be invoked to rationalise the experimental results [40]. For D-xylo aldohexos-5-ulose derivatives almost only one iminosugar (D-gluco) is obtained with a negligible influence of the structure of the amine used and of the protecting group pattern present on the dicarbonyl substrate [33, 41], while a more complicated picture is found for L-arabino aldohexos-5-ulose derivatives. For the deprotected compound, again only a sole iminosugar (D-galacto) was isolated even when performing the reaction with the quite hindered benzhydrylamine, whereas the two possible stereoisomers (D-galacto/L-altro 4:1 ratio) were obtained when using the 2,6di-O-benzyl L-arabino aldohexos-5-ulose derivative. [42] Furthermore, the steric hindrance of the employed amine had an effect on the stereoselectivity. Therefore, these literature results suggest that both the different C-4 stereochemistry of L-arabino aldohexos-5-ulose derivatives and the protecting groups present can play an important role in determining the stereochemical outcome of the reaction. Indeed, for the 6-deoxy 2-O-benzyl-L-arabinoderivative studied here, the results are in line with the previous findings for most of the amines (Table 1). Usually both D-galacto and L-altro 1,6-dideoxy nojirimycin derivatives were isolated with the first being the most abundant. The ratio between these two isomers span from 8:2 to $7: 3$ (entries 1-3, 6 and 8) with the exception of the more hindered benzhydrylamine derivative (entry 4 ) where an almost equal amount of the two isomeric iminosugars was obtained. The results obtained with hydroxylamine (entry 5), when complete selectivity for the D-galacto configuration was observed, and with D- or L-PheOMe (entries 7 and 8), where the ratio of the two iminosugars product was reversed, point to the need to consider other features of the amine partner beside its steric hindrance. 
Indeed, it appears that additional interactions between the reacting amine, the substituents or the hydroxy groups present on the dicarbonyl compound can come into play in determining the conformation and the reactivity of the preferred cyclic iminium ion. Further studies in this direction are currently underway.

It has also to be mentioned that an aminocyclization reaction employing amino acids has already been reported in the literature [43]. However, in that case the amino group involved in the reaction was on the side chain of a protected lysine, which is probably too far from the chiral centre to affect the stereoselectivity of the reaction.

To compare the experimental data with the literature, compounds $6 \mathrm{c}$ and $7 \mathrm{c}$ were further transformed into the deprotected compounds 14 [44] and 15 [44, 45] (Scheme 4) by means of catalytic hydrogenolysis $\left(\mathrm{H}_{2}, \mathrm{Pd} / \mathrm{C} 10 \%\right.$ in $\left.\mathrm{MeOH}\right)$ in the presence of $\mathrm{HCl}$, a set of conditions employed to avoid the previously reported $\mathrm{N}$-methylation side reaction [46].
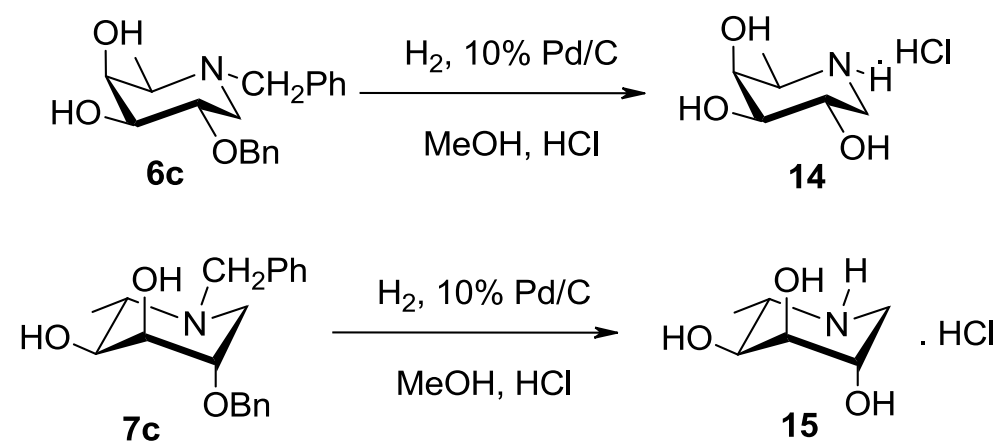

Scheme 4. Catalytic hydrogenolysis of iminosugars $6 \mathrm{c}$ and $7 \mathrm{c}$.

\section{Conclusions}

The preparation of a 2-O-benzyl-6-deoxy-L-arabino-hexos-5-ulose from lactose and its conversion into 1,6-di-deoxy-D-galacto and 1,6-di-deoxy-L-altro nojirimycin derivatives exploiting a reductive aminocyclization reaction were reported. This approach allowed for the preparation of a structurally-related family of iminosugars by simply selecting different ammonium salts. However, a limitation of the method lies in the difficulty encountered in the separation of the diastereoisomeric iminosugars. Of a certain interest is the observed inversion of selectivity when the enantiomeric amino acids were employed in the aminocyclization reaction, and the formation of only the iminosugar of the D-galacto configuration with hydroxylamine. 


\section{Experimental}

\subsection{General methods}

Melting points were determined with a Kofler hot-stage apparatus and are uncorrected. Optical rotations were measured at room temperature $\left(20 \pm 2{ }^{\circ} \mathrm{C}\right)$ in a $1 \mathrm{dm}$ cell with a Perkin-Elmer 241 polarimeter. NMR spectra were recorded with a Bruker AC 200 instrument operating at $200.13 \mathrm{MHz}\left({ }^{1} \mathrm{H}\right)$ and $50.33 \mathrm{MHz}\left({ }^{13} \mathrm{C}\right)$ in the stated solvent $\left(\mathrm{Me}_{4} \mathrm{Si}\right.$ was used as the internal standard, unless stated otherwise). Assignments were made, when possible, with the aid of DEPT, HETCOR, by comparison of values for known compounds and applying the additivity rules [47]. In the case of mixtures, assignments were made by referring to the differences in the peak intensities. All reactions were followed by TLC on Kieselgel $60 \mathrm{~F}_{254}$ (Merk) with detection by UV light and/or with 10\% phosphomolybdic acid or sulphuric acid in $\mathrm{EtOH}$ and heating, or exposure to $\mathrm{I}_{2}$ vapours. Kieselgel 60 (E. Merck, 70-230 and 230-400 mesh, respectively) was used for column and flash chromatography. Solvents were dried and purified by distillation according to standard procedures [48], and stored over $4 \AA$ molecular sieves activated for at least $24 \mathrm{~h}$ at $250{ }^{\circ} \mathrm{C} . \mathrm{MgSO}_{4}$ was used as the drying agent for solutions. Unless otherwise stated, all reactions requiring anhydrous conditions were carried out under Argon or Nitrogen. Elemental analysis was used to determine the purity of compounds. Analytical results are within $\pm 0.40 \%$ of the theoretical values.

The following standard procedure was used for acetylation: a solution of the compound $(1.0 \mathrm{mmol})$ in a $2: 1(\mathrm{v} / \mathrm{v})$ mixture $(6 \mathrm{~mL})$ of pyridine and $\mathrm{Ac}_{2} \mathrm{O}$ was stirred at room temperature for 12-24 $\mathrm{h}$, and then repeatedly co-evaporated under diminished pressure with toluene, and the residue was purified by flash chromatography on silica. "Solid foam" refers to amorphous compounds, recovered pure by chromatography for which all attempts to crystallize failed.

\subsection{Experimental procedures}

4.2.1. Reaction of 4-O-(2-O-benzyl-6-deoxy-3,4-O-isopropylidene- $\alpha$-L-arabino-hex-5enopyranosyl)-2,3:5,6-di-O-isopropylidene-aldehydo-dimethyl acetal (1) with $\mathrm{MeOH}$ catalyzed by $\mathrm{PPh}_{3} \cdot \mathrm{HBr}$.

A solution of 1 [34] $(2.02 \mathrm{~g}, 3.48 \mathrm{mmol})$ in dry $\mathrm{CH}_{2} \mathrm{Cl}_{2}(17.0 \mathrm{~mL})$ was treated at room temperature with $\mathrm{PPh}_{3} \cdot \mathrm{HBr}(60.2 \mathrm{mg}, 0.175 \mathrm{mmol})$ and dry $\mathrm{MeOH}(1.40 \mathrm{~mL}, 34.2 \mathrm{mmol})$, and the mixture reaction was stirred at room temperature until the starting material 
completely disappeared (TLC, 1:3 $\mathrm{Et}_{2} \mathrm{O}$-toluene). After $30 \mathrm{~min}$, TLC analysis (EtOAc) showed the prevalent formation of $2\left(R_{f} 0.73\right)$ and small amount of products $3\left(R_{f} 0.54\right)$ and $4\left(\mathrm{R}_{f} 0.50\right)$. The reaction solution was washed with satd aq $\mathrm{NaHCO}_{3}(3 \times 30 \mathrm{~mL})$ and the aqueous phases were collected and extracted with $\mathrm{CH}_{2} \mathrm{Cl}_{2}(4 \times 30 \mathrm{~mL})$. The combined organic phases were dried, filtered and concentrated. Purification of the crude residue (syrup, $2.96 \mathrm{~g}$ ) by flash chromatography on silica gel $(7: 3 n$-hexane-EtOAc $+0.1 \%$ of $\mathrm{Et}_{3} \mathrm{~N}$ ) afforded pure $2(1.17 \mathrm{~g}, 55 \%$ yield), 3 (319 mg, 16\% yield) and 4 (159 mg, 8\% yield). 4-O-[(5R)-(2-O-Benzyl-6-deoxy-3,4-O-isopropylidene-5-C-methoxy- $\alpha$-L-hexopyranosyl]2,3:5,6-di-O-isopropylidene-aldehydo-D-glucose dimethyl acetal (2). Clear syrup; $\mathrm{R}_{f} 0.73$ (EtOAc); $[\alpha]_{D}+7.5\left(c 1.0, \mathrm{CHCl}_{3}\right) ;{ }^{1} \mathrm{H}$ NMR $\left(\mathrm{CD}_{3} \mathrm{CN}, 200.13 \mathrm{MHz}\right): \delta$ 7.38-7.28 (m, 5H, ArH), 4.75 (d, $\left.1 \mathrm{H}, J_{1^{\prime}, 2^{\prime}} 8.4 \mathrm{~Hz}, \mathrm{H}-1^{\prime}\right), 4.80,4.68$ (AB system, $2 \mathrm{H}, J_{\mathrm{A}, \mathrm{B}} 12.1 \mathrm{~Hz}, \mathrm{CH}_{2} \mathrm{Ph}$ ), 4.47 (dd, $\left.1 \mathrm{H}, J_{1,2} 6.4 \mathrm{~Hz}, J_{2,3} 7.2 \mathrm{~Hz}, \mathrm{H}-2\right), 4.38(\mathrm{~d}, 1 \mathrm{H}, \mathrm{H}-1), 4.23\left(\mathrm{~d}, 1 \mathrm{H}, J_{4,5}=J_{5,6 a}=J_{5,66} 5.9 \mathrm{~Hz}\right.$, H-5), 4.15-4.06 (m, 3H, H-3', H-4, H-6a), 3.93 (d, 1H, J', $\left.3^{\prime}, 5.3 \mathrm{~Hz}, \mathrm{H}-4^{\prime}\right), 3.91$ (dd, 1H, J6a,6b $8.6 \mathrm{~Hz}, \mathrm{H}-6 \mathrm{~b}$ ), 3.86 (dd, $1 \mathrm{H}, J_{3,4} 1.3 \mathrm{~Hz}, \mathrm{H}-3$ ), 3.38, 3.39 (2s, each $\left.3 \mathrm{H}, \mathrm{OMe}-1\right), 3.29$ (s, $\left.3 \mathrm{H}, \mathrm{OMe}-5^{\prime}\right), 3.25$ (bt, $\left.1 \mathrm{H}, \mathrm{J}_{2^{\prime}, 3^{\prime}} 8.0 \mathrm{~Hz}, \mathrm{H}-2^{\prime}\right) ; 2.20$ (s, 3H, H-6'), 1.37, 1.36, 1.35, 1.29, 1.28, 1.27 (6s, each $\left.3 \mathrm{H}, 3 \times \mathrm{CMe}_{2}\right) ;{ }^{13} \mathrm{C} \mathrm{NMR}\left(\mathrm{CD}_{3} \mathrm{CN}, 50.33 \mathrm{MHz}\right): \delta 139.7$ (Ar-C), 129.1, 129.0, 128.4 (Ar- $\mathrm{CH}$ ), 110.5, 109.9, $109.3\left(3 \times \mathrm{CMe}_{2}\right.$ ), 106.7 (C-1), 100.5 (C-5'), 98.7 (C-1'), 80.3, 78.9, 78.9, 77.8, 78.8 (C-2', C-3', C-2, C-3, C-4), 76.8, 76.1 (C-4', C-5), 74.3 $\left(\mathrm{CH}_{2} \mathrm{Ph}\right), 66.2$ (C-6), 56.5, 53.8 (2×OMe-1), 48.3 (OMe-5'), 28.3, 27.5, 27.1, 26.9, 26.6, $25.6\left(3 \times \mathrm{CMe}_{2}\right), 19.4\left(\mathrm{C}-6^{\prime}\right)$. Anal. Calcd for $\mathrm{C}_{31} \mathrm{H}_{48} \mathrm{O}_{12}$ : C, 60.77; H, 7.90. Found: C, 60.49; $\mathrm{H}, 7.61$.

4-O-[(5R)-(2-O-benzyl-6-deoxy-5-C-methoxy- $\alpha$-L-hexopyranosyl]-2,3:5,6-di-O-isopropylidene-aldehydo-D-glucose dimethyl acetal (3). Clear syrup; $R_{f} 0.54$ (EtOAc); $[\alpha]_{D}-7.4$ (c 1.3, $\left.\mathrm{CHCl}_{3}\right) ;{ }^{1} \mathrm{H}$ NMR $\left(\mathrm{CDCl}_{3}, 200.13 \mathrm{MHz}\right): \delta$ 7.34-7.27 (m, 5H, Ar-H), $4.91\left(\mathrm{~d}, 1 \mathrm{H}, J_{1^{\prime}, 2^{\prime}}\right.$ $\left.7.8 \mathrm{~Hz}, \mathrm{H}-1^{\prime}\right), 4.96,4.80$ (AB system, $2 \mathrm{H}, \mathrm{J}_{\mathrm{A}, \mathrm{B}} 11.6 \mathrm{~Hz}, \mathrm{CH}_{2} \mathrm{Ph}$ ), 4.75-4.49 (m, 2H, H-2, H5), 4.40 (d, $\left.1 \mathrm{H}, J_{1,2} 6.4 \mathrm{~Hz}, \mathrm{H}-1\right), 4.34-3.83$ (m, 6H, H-3, H-4, H-6a, H-6b, H-2', H-3'), 3.68 (d, $1 \mathrm{H}, J_{3^{\prime}, 4^{\prime}} 3.2 \mathrm{~Hz}, \mathrm{H}-4^{\prime}$ ), 3.43, 3.41 (2s, each 3H, 2×OMe-1), 3.29 (s, 3H, OMe-5'), 1.47, $1.44,1.43,1.38,1.34\left(5 \mathrm{~s}\right.$, each $\left.3 \mathrm{H}, 2 \times \mathrm{CMe}_{2}, \mathrm{H}-6^{\prime}\right) ;{ }^{13} \mathrm{C} \mathrm{NMR}\left(\mathrm{CDCl}_{3}, 50.33 \mathrm{MHz}\right): \delta 138.4$ (Ar-C), 128.5, 128.2, $127.8(\mathrm{Ar}-\mathrm{CH}), 110.0,108.4\left(2 \times \mathrm{CMe}_{2}\right), 105.3$ (C-1), 100.9 (C-5'), 98.8 (C-1'), 78.7, 77.9, 77.7, 77.6 (C-2', C-2, C-3, C-4), 74.5 (C-5), $74.4\left(\mathrm{CH}_{2} \mathrm{Ph}\right), 72.5$, 70.2 (C-3', C-4'), 65.2 (C-6), 55.6, 52.7 (2×OMe-1), 47.8 (OMe-5'), 27.3, 26.7, 26.5, 25.1 $\left(2 \times \mathrm{CMe}_{2}\right), 18.6$ (C-6'). Anal. Calcd for $\mathrm{C}_{28} \mathrm{H}_{44} \mathrm{O}_{12}: \mathrm{C}, 58.73 ; \mathrm{H}, 7.74$. Found: $\mathrm{C}, 58.65 ; \mathrm{H}$, 7.70 . 
4-0-[(5R)-(2-O-benzyl-6-deoxy-3,4-O-isopropylidene-5-C-methoxy- $\alpha$-L-hexopyranosyl]2,3-O-isopropylidene-aldehydo-D-glucose dimethyl acetal (4). Clear syrup; $R_{f} 0.40$ (EtOAc); $[\alpha]_{D}=-12.8\left(c\right.$ 1.8, $\left.\mathrm{CHCl}_{3}\right) ;{ }^{1} \mathrm{H}$ NMR $\left(\mathrm{CDCl}_{3}, 200.13 \mathrm{MHz}\right): \delta 7.41-7.27(\mathrm{~m}, 5 \mathrm{H}$, Ar-H), 4.88, 4.72 (AB system, 2H, JA,B $11.4 \mathrm{~Hz}, \mathrm{CH}_{2} \mathrm{Ph}$ ), 4.71 (d, $\left.1 \mathrm{H}, J_{1^{\prime}, 2^{\prime}} 7.2 \mathrm{~Hz}, \mathrm{H}-1^{\prime}\right)$, 4.60 (dd, $\left.1 \mathrm{H}, J_{1,2} 6.4 \mathrm{~Hz}, J_{2,3} 7.4 \mathrm{~Hz}, \mathrm{H}-2\right), 4.39$ (d, $\left.1 \mathrm{H}, \mathrm{H}-1\right)$, 4.07- $3.72(\mathrm{~m}, 7 \mathrm{H}, \mathrm{H}-3, \mathrm{H}-4$, H-5, H-6a, H-6b, H-3', H-4'), 3.42 (m, 1H, H-2'), 3.43, 3.41 (2s, each 3H, 2 x OMe-1), 3.30 (s, 3H, OMe-5'), 1.44, 1.43, 1.41, 1.38, 1.34 (5s, each $\left.3 \mathrm{H}, 2 \times \mathrm{CMe}_{2}, \mathrm{H}-6{ }^{\prime}\right) ;{ }^{13} \mathrm{C} \mathrm{NMR}$ $\left(\mathrm{CDCl}_{3}, 50.33 \mathrm{MHz}\right): \delta 137.4(\mathrm{Ar}-\mathrm{C}), 128.4,128.2,127.7(\mathrm{Ar}-\mathrm{CH}), 110.0,109.3\left(2 \times \mathrm{CMe}_{2}\right)$, 105.4 (C-1), 99.6 (C-5'), 97.8 (C-1'), 79.2, 78.4, 77.9, 77.6, 77.5 (C-2', C-3', C-2, C-3, C-4), 75.2 (C-4'), 73.45 (C-5), $73.2\left(\mathrm{CH}_{2} \mathrm{Ph}\right.$ ), 62.5 (C-6), 56.1, 52.7 (2×OMe-1), 47.5 (OMe-5'), 27.9, 27.2, 26.4, $26.3\left(2 \times \mathrm{CMe}_{2}\right), 19.1$ (C-6'). Anal. Calcd for $\mathrm{C}_{28} \mathrm{H}_{44} \mathrm{O}_{12}$ : C, 58.73; H, 7.74. Found: C, 58.55; H, 7.70.

\subsubsection{6-deoxy-2-O-benzyl-L-arabino-hexos-5-ulose (5).}

Method A (from 1 with TFA- $\mathrm{H}_{2} \mathrm{O}$ ): A solution 1 [34] $(6.10 \mathrm{~g}, 10.5 \mathrm{mmol})$ in $4: 1(\mathrm{v} / \mathrm{v}) \mathrm{CH}_{3} \mathrm{CN}$ $\mathrm{H}_{2} \mathrm{O}(160 \mathrm{~mL})$ was treated with $90 \%$ aq $\mathrm{CF}_{3} \mathrm{COOH}(14.4 \mathrm{~mL})$ and stirred at room temperature. After $18 \mathrm{~h}$, TLC analysis (3:7 hexane-EtOAc) showed the complete disappearance of the starting material and the formation of two products $\left(R_{f} 0.47\right.$ and 0.0$)$, the first of them $\left(R_{f} 0.47\right)$ visible under UV light. The solution was concentrated under diminished pressure and repeatedly co-evaporated with toluene $(5 \times 20 \mathrm{~mL})$. The crude residue was partitioned between EtOAc $(80 \mathrm{~mL})$ and satd aq $\mathrm{NaHCO}_{3}(40 \mathrm{~mL})$ and the aqueous phase extracted with EtOAc $(4 \times 30 \mathrm{~mL})$. The combined organic extracts were dried and concentrated to give a crude residue $(2.41 \mathrm{~g}, 91 \%$ yield) constituted (NMR) exclusively by a $4: 1$ mixture of $\alpha$ - and $\beta$-1,4-furanose anomers ( $5 \alpha$ and $5 \beta$ ) measured on the relative intensities two $C-1$ signals at $\delta 102.3$ and 97.6 respectively. Purification of the crude product by flash chromatography on silica gel (3:2 hexane-EtOAc) gave pure 5 ( $2.25 \mathrm{~g}, 85 \%$ yield) as white foam; $\mathrm{R}_{f} 0.47$ (3:7 hexane-EtOAc); $[\alpha]_{D}+6.9^{\circ}$ (c 1.2, $\mathrm{CHCl}_{3}$ ); ${ }^{1} \mathrm{H}$ NMR ( $\left.\mathrm{CD}_{3} \mathrm{CN}, 200.13 \mathrm{MHz}\right)$ : anomer 5a: $\delta 5.41\left(\mathrm{~d}, 1 \mathrm{H}, J_{1,2} 1.1 \mathrm{~Hz}, \mathrm{H}-1\right), 4.48(\mathrm{~d}, 1 \mathrm{H}$, $\left.J_{3.4} 3.8 \mathrm{~Hz}, \mathrm{H}-4\right), 4.27$ (dd, 1H, J2,3 $2.2 \mathrm{~Hz}, \mathrm{H}-3$ ), 3.84 (dd, 1H, H-2), 2.14 (s, 3H, H-6); anomer $5 \beta$ : $\delta 5.43\left(\mathrm{~d}, 1 \mathrm{H}, J_{1,2} 3.9 \mathrm{~Hz}, \mathrm{H}-1\right.$ ), $4.10\left(\mathrm{~d}, 1 \mathrm{H}, J_{3,4} 4.5 \mathrm{~Hz}, \mathrm{H}-4\right), 4.38$ (dd, $1 \mathrm{H}, J_{2,3}$ $5.0 \mathrm{~Hz}, \mathrm{H}-3), 3.79(\mathrm{dd}, 1 \mathrm{H}, \mathrm{H}-2), 2.21(\mathrm{~s}, 3 \mathrm{H}, \mathrm{H}-6)$, cluster of signals for both anomers $\delta$ 7.39-7.25 (m, 10H, Ar- $H)$, 4.62-4.45 (m, 4H, $\left.2 \times \mathrm{CH}_{2} \mathrm{Ph}\right) ;{ }^{13} \mathrm{C}$ NMR $\left(\mathrm{CD}_{3} \mathrm{CN}, 50.33 \mathrm{MHz}\right)$ anomer 5a: $\delta 209.8$ (C-5), $102.3(\mathrm{C}-1), 90.0$ (C-4), $88.7(\mathrm{C}-2), 77.8(\mathrm{C}-3), 72.3\left(\mathrm{CH}_{2} \mathrm{Ph}\right)$, 26.7 (C-6); anomer 5B: $\delta 211.2$ (C-5), 97.6 (C-1), 87.8 (C-4), 83.9 (C-2), 76.3 (C-3), 72.8 
$\left(\mathrm{CH}_{2} \mathrm{Ph}\right), 26.7$ (C-6), cluster of signals for both anomers $\delta 138.7$ (2xAr-C), 129.4-127.8 (Ar-CH). Anal. Calcd for $\mathrm{C}_{13} \mathrm{H}_{16} \mathrm{O}_{5}$ (252.10): C, 61.90; H, 6.39. Found: C, 61.75; H, 6.35.

Method B (from crude mixture 2, 3 and 4, with TFA- $\mathrm{H}_{2} \mathrm{O}$ ): the crude mixture of 5-Cmethoxy derivatives 2, 3 and 4, obtained by $\mathrm{MeOH}$ addition of $\mathbf{1}(760 \mathrm{mg}, 1.31 \mathrm{mmol})$, was dissolved in 4:1 $(v / v) \mathrm{CH}_{3} \mathrm{CN} / \mathrm{H}_{2} \mathrm{O}$ and treated with $90 \%$ aq $\mathrm{CF}_{3} \mathrm{COOH}$ in $\mathrm{CH}_{3} \mathrm{CN}-\mathrm{H}_{2} \mathrm{O}$ according to the procedure described above for the reaction of 1 . Purification of the crude product $(280 \mathrm{mg})$ by flash chromatography on silica gel (3:2 hexane-EtOAc) led to a $4: 1$ mixture of $\mathbf{5} \boldsymbol{\alpha}$ and $\mathbf{5} \boldsymbol{\beta}$ ( $251 \mathrm{mg}, 76 \%$ yield) having NMR parameters identical to those of the samples prepared above.

\subsubsection{General procedures for the double reductive amination of 6-deoxy-2-0-benzyl-} L-arabino-hexos-5-ulose (5).

Method $A$ - To a solution of the $4: 1$ mixture of $\mathbf{5 \alpha}, \boldsymbol{\beta}(1.0 \mathrm{mmol})$ in dry $\mathrm{MeOH}(15 \mathrm{~mL})$, a solution of the opportune amine salt $(10 \mathrm{mmol})$ in dry $\mathrm{MeOH}(22 \mathrm{~mL})$ and then a solution of $\mathrm{NaBH}_{3} \mathrm{CN}(2.2 \mathrm{mmol})$ in dry $\mathrm{MeOH}(15 \mathrm{~mL})$ were added. The mixture was warmed to 60 ${ }^{\circ} \mathrm{C}$ and left under stirring until the starting material was completely disappeared (TLC analysis, 5-24 h). The reaction mixture was cooled to room temperature, quenched by addition of $1 \%$ methanolic $\mathrm{HCl}$, and stirred until a persistent $\mathrm{pH} 1$ value was reached (50 min). The solution was neutralized by addition of solid $\mathrm{NaHCO}_{3}(\mathrm{pH} 7-8)$, stirred at room temperature (30 $\mathrm{min}$ ) and the suspension was filtered, the residue washed with $\mathrm{MeOH}$ and the organic phase was concentrated under diminished pressure. The crude residue was partitioned between EtOAc $(40 \mathrm{~mL})$ containing $\mathrm{Et}_{3} \mathrm{~N}(0.5 \mathrm{~mL})$ and $\mathrm{NaHCO}_{3}$ satd aq solution $(30 \mathrm{~mL})$ and the aqueous phase extracted with EtOAc $(4 \times 30 \mathrm{~mL})$. The combined organic extracts were dried and concentrated at diminished pressure. The crude residue was analyzed by NMR $\left({ }^{1} \mathrm{H}\right.$ and $\left.{ }^{13} \mathrm{C}\right)$ and subjected to a flash chromatographic purification on silica gel eluting with opportune solvent mixtures.

Method $B-A$ solution of the $4: 1$ mixture of $5 \boldsymbol{\alpha}, \boldsymbol{\beta}(1.0 \mathrm{mmol})$ in dry $\mathrm{MeOH}(6 \mathrm{~mL})$ was treated with a solution of opportune amine salt $(1.0 \mathrm{mmol})$ in dry $\mathrm{MeOH}(9 \mathrm{~mL})$ and with a solution of $\mathrm{NaBH}_{3} \mathrm{CN}(2.0 \mathrm{mmol})$ in dry $\mathrm{MeOH}(6 \mathrm{~mL})$. The reaction mixture was stirred at $60{ }^{\circ} \mathrm{C}$ until the starting material was completely disappeared (TLC analysis, 18-24 h). The solution was concentrated under diminished pressure and the crude residue was partitioned between with EtOAc $(40 \mathrm{~mL})$ and satd aq $\mathrm{NaHCO}_{3}$ solution $(20 \mathrm{~mL})$. The aqueous phase was extracted with EtOAc $(4 \times 30 \mathrm{~mL})$ and the organic layers were collected, dried and concentrated in diminished pressure. The crude residue was analyzed 
by NMR $\left({ }^{1} \mathrm{H}\right.$ and $\left.{ }^{13} \mathrm{C}\right)$ and subjected to a flash chromatographic purification on silica gel eluting with opportune solvent mixtures.

\subsubsection{2-O-benzyl-1,5,6-trideoxy-1,5-imino-D-galactitol (6a) and 2-O-benzyl-1,5,6- trideoxy-1,5-imino-L-altritol (7a).}

A solution of $5 \alpha, \beta$ (300 $\mathrm{mg}, 1.19 \mathrm{mmol}$ ) was subjected to double reductive amination with ammonium formate $(748 \mathrm{mg}, 11.9 \mathrm{mmol})$ and $\mathrm{NaBH}_{3} \mathrm{CN}(149 \mathrm{mg}, 2.38 \mathrm{mmol}$ ) according to the general procedure (Method $\mathrm{A}$ ). The reaction was complete after $17 \mathrm{~h}$ and TLC analysis (6:4 EtOAc-MeOH) showed the formation of only one spot $\left(R_{f} 0.30\right)$. The crude residue (syrup, $203 \mathrm{mg}$ ) was constituted $\left(\mathrm{NMR}, \mathrm{CD}_{3} \mathrm{CN}\right)$ by a mixture of compounds $6 \mathbf{a}$ and $7 \mathrm{a}$ in a 75:25 ratio, measured on the relative intensities of the C-1 signals at $\delta 45.7$ and 42.9 respectively. Compound $6 \mathbf{a}$ and $7 \mathbf{a}$ were inseparable by TLC with several elution systems and purification of the crude product by flash chromatography on silica gel (3:1 EtOAc-MeOH $+0.1 \% \mathrm{Et}_{3} \mathrm{~N}$ ) afforded pure mixture of $6 \mathbf{a}+\mathbf{7 a}(193 \mathrm{mg}, 68 \%$ yield) as a clear

syrup; $\mathrm{R}_{f} 0.30$ (6:4 EtOAc-MeOH); selected ${ }^{1} \mathrm{H}$ NMR $\left(\mathrm{CDCl}_{3}, 200.13 \mathrm{MHz}\right)$ signals: compound 6a $\delta 4.58\left(\mathrm{~s}, 2 \mathrm{H}, \mathrm{OCH}_{2} \mathrm{Ph}\right), 1.01\left(\mathrm{~d}, 1 \mathrm{H}, \mathrm{J}_{5,6} 6.4 \mathrm{~Hz}, \mathrm{H}-6\right)$; for $7 \mathrm{a} \delta$ 4.54, 4.46 (AB system, 2H, $\left.\mathrm{J}_{\mathrm{A}, \mathrm{B}} 12.2 \mathrm{~Hz}, \mathrm{OCH} \mathrm{Ph}_{2}\right), 1.17$ (d, $\left.1 \mathrm{H}, \mathrm{J}_{5,6} 7.0 \mathrm{~Hz}, \mathrm{H}-6\right) ;{ }^{13} \mathrm{C} \mathrm{NMR}\left(\mathrm{CDCl}_{3}\right.$, $50.33 \mathrm{MHz}$ ): compound 6a: $\delta 138.3(\mathrm{Ar}-\mathrm{C}), 76.9(\mathrm{C}-2), 75.2(\mathrm{C}-3), 72.2\left(\mathrm{OCH}_{2} \mathrm{Ph}\right), 72.1$ (C-4), 53.8 (C-5), 47.7 (C-1), 17.2 (C-6); compound 7a: $\delta 137.9$ (Ar-C), 76.8 (C-2), 72.0 (C-3), $70.0\left(\mathrm{OCH}_{2} \mathrm{Ph}\right) ; 68.7$ (C-4), 50.9 (C-5), 45.7 (C-1), 17.6 (C-6); cluster of signals for both diastereoisomers: $\delta$ 128.2-127.5 (Ar-CH). Anal. Calcd for $\mathrm{C}_{13} \mathrm{H}_{19} \mathrm{NO}_{3}: \mathrm{C}, 65.80 ; \mathrm{H}$, 8.07; N, 5.90. Found: C, 65.83; H, 8.10; N, 5.92.

\subsubsection{2-O-benzyl-1,5,6-trideoxy-1,5-imino- $\mathrm{N}$-methyl-D-galactitol (6b) and 2-O-benzyl- 1,5,6-trideoxy-1,5-imino- $N$-methyl-L-altritol (7b).}

The double reductive amination of $\boldsymbol{5} \alpha, \beta(354 \mathrm{mg}, 1.40 \mathrm{mmol})$ with $\mathrm{CH}_{3} \mathrm{NH}_{3} \mathrm{Cl}(1.02 \mathrm{~g}, 15.1$ $\mathrm{mmol}$ ) and $\mathrm{NaBH}_{3} \mathrm{CN}$ (192 $\mathrm{mg}, 3.05 \mathrm{mmol}$ ) was performed in accordance to the general procedure (Method A). After $5 \mathrm{~h}$, TLC analysis (EtOAc) showed the complete disappearance of the starting material and the formation of only one spot $\left(R_{f} 0.10\right)$. The crude residue ( $350 \mathrm{mg}$ ) was constituted (NMR) by a mixture of $6 \mathbf{b}$ and $7 \mathbf{b}$ in a 80:20 ratio, estimated on the relative intensities of two separated singlets attributed to $\mathrm{N}-\mathrm{CH}_{3}$ at $\delta 2.23$ and 2.31, respectively. Several attempts to separate the components of the mixture through TLC gave negative results. Purification of the crude product by flash chromatography on silica gel $\left(6: 4 \mathrm{CH}_{2} \mathrm{Cl}_{2}-{ }^{\mathrm{i}} \mathrm{PrOH}+0.1 \% \mathrm{Et}_{3} \mathrm{~N}\right)$ gave a mixture of pure $\mathbf{6 b}$ 
and $7 \mathbf{b}$ (217 mg, 62\% yield) as a clear syrup; $\mathrm{R}_{f} 0.15\left(6: 4 \mathrm{CH}_{2} \mathrm{Cl}_{2}-{ }^{\mathrm{i}} \mathrm{PrOH}\right) ;{ }^{1} \mathrm{H} \mathrm{NMR}\left(\mathrm{CDCl}_{3}\right.$, $200.13 \mathrm{MHz}$ ) compound $6 \mathrm{~b}$ : $\delta$ 4.69, 4.62 (AB system, $2 \mathrm{H}, \mathrm{J}_{\mathrm{A}, \mathrm{B}} 11.7 \mathrm{~Hz}, \mathrm{OCH}_{2} \mathrm{Ph}$ ), 3.70 (m, 2H, H-2, H-4), 3.44 (dd, $1 \mathrm{H}, J_{2,3} 9.3 \mathrm{~Hz}, J_{3,4} 3.3 \mathrm{~Hz}, \mathrm{H}-3$ ), 3.06 (dd, $1 \mathrm{H}, J_{\text {lax, 1eq }} 11.2 \mathrm{~Hz}$,

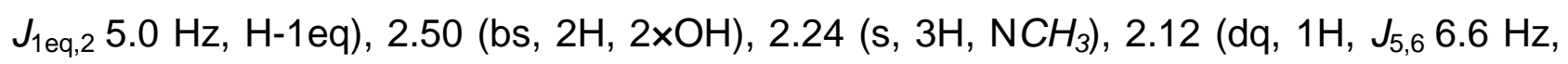
$J_{4,5} 1.1 \mathrm{~Hz}, \mathrm{H}-5$ ), 1.98 (dd, 1H, J $J_{1 a x, 2} 10.7 \mathrm{~Hz}, \mathrm{H}-1 \mathrm{ax}$ ), 1.11 (d, 3H, H-6); compound 7b: selected signals $\delta 4.56\left(\mathrm{~s}, 2 \mathrm{H}, \mathrm{OCH}_{2} \mathrm{Ph}\right), 2.31$ (s, 3H, NCH ), 1.05 (d, 3H, $\left.\mathrm{J}_{5,6} 6.8 \mathrm{~Hz}, \mathrm{H}-6\right)$; cluster of signals for both diastereoisomers: $\delta$ 7.37-7.27 (m, 10H, Ar- $H)$; ${ }^{13} \mathrm{C} \mathrm{NMR}\left(\mathrm{CDCl}_{3}\right.$, $50.33 \mathrm{MHz}$ ): compound 6b: $\delta 138.3$ (Ar-C), 76.3 (C-2), 75.5 (C-3), 73.4 (C-4), 72.2 $\left(\mathrm{OCH}_{2} \mathrm{Ph}\right) ; 60.7$ (C-5), 58.5 (C-1), $42.1\left(\mathrm{NCH}_{3}\right), 16.4$ (C-6); compound 7b: $\delta 138.1$ (Ar-C), 75.8 (C-2), $71.8\left(\mathrm{OCH}_{2} \mathrm{Ph}\right), 71.5$ (C-3), 69.4 (C-4), 59.1 (C-5), 51.8 (C-1), $41.9\left(\mathrm{NCH}_{3}\right)$, 10.7 (C-6); cluster of signals for both diastereoisomers: $\delta$ 128.2-127.6 (Ar- $\mathrm{CH})$. Anal. Calcd for $\mathrm{C}_{14} \mathrm{H}_{21} \mathrm{NO}_{3}: \mathrm{C}, 66.91 ; \mathrm{H}, 8.42 ; \mathrm{N}, 5.57$. Found: $\mathrm{C}, 66.89 ; \mathrm{H}, 8.38 ; \mathrm{N}, 5.54$.

4.2.6. 2-O-benzyl- $\mathrm{N}$-benzyl-1,5,6-trideoxy-1,5-imino-D-galactitol (6c) and 2-O-benzylN-benzyl-1,5,6-trideoxy-1,5-imino-L-altritol (7c).

A solution of $5 \alpha, \beta(1.09 \mathrm{~g}, 4.30 \mathrm{mmol})$ was subjected to double reductive amination with $\mathrm{PhCH}_{2} \mathrm{NH}_{3} \mathrm{Cl}(618 \mathrm{mg}, 4.30 \mathrm{mmol})$ and $\mathrm{NaBH}_{3} \mathrm{CN}(541 \mathrm{mg}, 8.61 \mathrm{mmol})$ in accordance to the general procedure (Method B). After $18 \mathrm{~h}, \mathrm{TLC}$ analysis (EtOAc) showed the complete disappearance of the starting material and the formation of two spots $\left(R_{f} 0.40\right.$ and 0.27$)$. NMR analysis of the crude residue (350 mg) showed a mixture of azapyranoses $6 \mathrm{c}$ and $7 \mathrm{c}$ in a 70:30 ratio, measured on the relative intensities of the $C$ - 1 signals at $\delta 54.1$ and 47.8 , respectively. Purification of the crude product by flash chromatography on silica gel (96:4 $\left.\mathrm{CH}_{2} \mathrm{Cl}_{2}{ }^{-} \mathrm{PrOH}+0.1 \% \mathrm{Et}_{3} \mathrm{~N}\right)$ afforded pure $6 \mathrm{c}(565 \mathrm{mg}, 40 \%$ yield) and pure $7 \mathrm{c}(225 \mathrm{mg}$, $16 \%$ yield).

2-O-benzyl-N-benzyl-1,5,6-trideoxy-1,5-imino-D-galactitol (6c). Crystalline solid; $\mathrm{R}_{f} 0.27$ (EtOAc); mp 84-87 ${ }^{\circ} \mathrm{C}$ (from $\left.\mathrm{Et}_{2} \mathrm{O}\right)$; $[\alpha]_{\mathrm{D}}-11.7$ (c 1.01, $\left.\mathrm{CHCl}_{3}\right) .{ }^{1} \mathrm{H}$ NMR $\left(\mathrm{CDCl}_{3}, 200.13\right.$ $\mathrm{MHz}): \delta$ 7.21-7.36 (m, 10H, Ar-H), 4.57, 4.50 (AB system, 2H, $\mathrm{J}_{\mathrm{A}, \mathrm{B}} 11.6 \mathrm{~Hz}, \mathrm{OCH}_{2} \mathrm{Ph}$ ), 3.74, 3.22 (AB system, 2H, $J_{A, B} 13.5 \mathrm{~Hz}, \mathrm{NCH}_{2} \mathrm{Ph}$ ), 3.61 (dd, $1 \mathrm{H}, J_{3,4} 3.0 \mathrm{~Hz}, J_{4,5} 1.4 \mathrm{~Hz}, \mathrm{H}$ 4), 3.51 (ddd, $1 \mathrm{H}, J_{1 \mathrm{ax}, 2} 9.8 \mathrm{~Hz}, J_{2,3} 9.1 \mathrm{~Hz}, J_{1 \mathrm{eq}, 2} 4.6 \mathrm{~Hz}, \mathrm{H}-2$ ), 3.43 (dd, $1 \mathrm{H}, \mathrm{H}-3$ ), 3.06 (dd, $1 \mathrm{H}, J_{\text {lax,1eq }} 11.3 \mathrm{~Hz}, \mathrm{H}-1 \mathrm{eq}$ ), 2.49 (dq, $1 \mathrm{H}, J_{5,6} 6.5 \mathrm{~Hz}, \mathrm{H}-5$ ), 2.47 (bs, 2H, 2×OH), 1.83 (dd, $1 \mathrm{H}, \mathrm{H}-1 \mathrm{ax}), 1.36(\mathrm{~d}, 3 \mathrm{H}, \mathrm{H}-6) ;{ }^{13} \mathrm{C}$ NMR $\left(\mathrm{CDCl}_{3}, 50.33 \mathrm{MHz}\right): \delta 138.2,137.9(2 \times \mathrm{Ar}-\mathrm{C})$, 128.7-126.9 (Ar- $\mathrm{CH}), 76.5$ (C-2), 75.6 (C-3), 74.0 (C-4), $72.1\left(\mathrm{OCH}_{2} \mathrm{Ph}\right), 58.6$ (C-5), 56.4 ( $\mathrm{NCH}_{2} \mathrm{Ph}$ ), 53.9 (C-1), 16.8 (C-6). Anal. Calcd for $\mathrm{C}_{20} \mathrm{H}_{25} \mathrm{NO}_{3}$ : C, 73.37; H, 7.70; N, 4.28. Found: C, 73.36; $\mathrm{H}, 7.68 ; \mathrm{N}, 4.30$. 
2-O-benzyl-N-benzyl-1,5,6-trideoxy-1,5-imino-L-altritol (7c). Clear syrup; $\mathrm{R}_{f} 0.40$ (EtOAc); $[\alpha]_{\mathrm{D}}+18.6$ (c 1.16, $\left.\mathrm{CHCl}_{3}\right) .{ }^{1} \mathrm{H}$ NMR $\left(\mathrm{CDCl}_{3}, 200.13 \mathrm{MHz}\right): \delta 7.38-7.21(\mathrm{~m}, 10 \mathrm{H}, \mathrm{Ar}-\mathrm{H})$, 4.65, 4.57 (AB system, 2H, JA, $12.0 \mathrm{~Hz}, \mathrm{OCH}_{2} \mathrm{Ph}$ ), 3.67 (m, 3H, H-2, H-3, H-4), 3.62 (s, $2 \mathrm{H}, \mathrm{NCH}_{2} \mathrm{Ph}$ ), 2.49 (bs, 2H, 2×OH), 3.08 (dq, 1H, J5,6 $6.9 \mathrm{~Hz}, J_{4,5} 2.3 \mathrm{~Hz}, \mathrm{H}-5$ ), 2.79 (dd, $1 \mathrm{H}, J_{\text {lax, 1eq }} 11.5 \mathrm{~Hz}, J_{1 \text { eq, } 2} 5.3 \mathrm{~Hz}, \mathrm{H}-1 \mathrm{eq}$ ), 2.42 (dd, 1H, J $J_{\text {ax }, 2} 9.8 \mathrm{~Hz}, \mathrm{H}-1 \mathrm{ax}$ ), 1.01 (d, 3H, $\mathrm{H}-6) ; \delta{ }^{13} \mathrm{C} \mathrm{NMR}\left(\mathrm{CDCl}_{3}, 50.33 \mathrm{MHz}\right): \delta 138.5,138.4(2 \times \mathrm{Ar}-\mathrm{C}), 128.8-126.9(\mathrm{Ar}-\mathrm{CH}), 77.3$ (C-2), 73.2 (C-3), $72.2\left(\mathrm{OCH}_{2} \mathrm{Ph}\right), 71.6$ (C-4), $57.9\left(\mathrm{NCH}_{2} \mathrm{Ph}\right), 57.4$ (C-5), 47.8 (C-1), 8.1 (C-6). Anal. Calcd for $\mathrm{C}_{20} \mathrm{H}_{25} \mathrm{NO}_{3}$ : C, 73.37; $\mathrm{H}, 7.70 ; \mathrm{N}, 4.28$. Found: $\mathrm{C}, 73.34 ; \mathrm{H}, 7.67 ; \mathrm{N}$, 4.26 .

\subsubsection{2-O-benzyl-N-benzydryl-1,5,6-trideoxy-1,5-imino-D-galactitol (6d) and 2-O- benzydryl-N-benzydryl-1,5,6-trideoxy-1,5-imino-L-altritol (7d).}

The double reductive amination of $5 \alpha, \beta(300 \mathrm{mg}, 1.19 \mathrm{mmol})$ was performed with $\mathrm{Ph}_{2} \mathrm{CHNH}_{3} \mathrm{Cl}$ (261 mg, $1.19 \mathrm{mmol}$ ) and $\mathrm{NaBH}_{3} \mathrm{CN}$ (149.4 mg, $2.34 \mathrm{mmol}$ ) according to the general procedure (Method $\mathrm{B}$ ). The reaction was complete after $18 \mathrm{~h}$ and TLC analysis (EtOAc) showed the complete disappearance of the starting material and the formation of a major spot $\left(\mathrm{R}_{f} 0.57\right)$. NMR analysis of the crude residue $(405 \mathrm{mg})$ showed a mixture of azapyranoses $\mathbf{6} \mathbf{d}$ and $\mathbf{7 d}$ in a $45: 55$ ratio estimated on the relative intensities of the $\mathbf{C}-1$ signals at $\delta 49.0$ and 45.6 respectively. Several attempts to separate the components of the mixture through TLC gave negative result. Purification of the crude product by flash chromatography on silica gel (60:35:5 hexane-EtOAc- $\left.\mathrm{PrOH}+0.1 \% \mathrm{Et}_{3} \mathrm{~N}\right)$ gave a mixture of pure $\mathbf{6} \mathbf{d}$ and $\mathbf{7 d}\left(312 \mathrm{mg}, 64 \%\right.$ yield) as a clear syrup; $\mathrm{R}_{f} 0.30$ (60:35:5 hexane-EtOAc'PrOH). ${ }^{1} \mathrm{H}$ NMR $\left(\mathrm{CDCl}_{3}, 200.13 \mathrm{MHz}\right.$ ) compound $6 \mathrm{~d}$ : $\delta 3.67$ (dd, $1 \mathrm{H}, J_{3,4} 3.3 \mathrm{~Hz}, J_{4,5} 1.6$ $\mathrm{Hz}, \mathrm{H}-4$ ), 3.62 (ddd, $1 \mathrm{H}, J_{1 \mathrm{ax}, 2} 10.0 \mathrm{~Hz}, J_{2,3} 8.8 \mathrm{~Hz}, J_{1 \mathrm{eq}, 2} 4.6 \mathrm{~Hz}, \mathrm{H}-2$ ), 3.33 (dd, $1 \mathrm{H}, \mathrm{H}-3$ ), 3.05 (dd, $1 \mathrm{H}, J_{1 \mathrm{ax}, 1 \mathrm{eq}} 11.5 \mathrm{~Hz}, \mathrm{H}-1 \mathrm{eq}$ ), 2.53 (dq, $1 \mathrm{H}, J_{5,6} 6.5 \mathrm{~Hz}, \mathrm{H}-5$ ), 1.77 (dd, $1 \mathrm{H}, \mathrm{H}-1 \mathrm{ax}$ ), 1.40 (d, 3H, H-6); compound 7d: 3.67 (m, 3H, H-2, H-3, H-4), 3.20 (dq, $1 \mathrm{H}, J_{5,6} 7.0 \mathrm{~Hz}, \mathrm{~J}_{4,5}$ $1.1 \mathrm{~Hz}, \mathrm{H}-5), 2.93$ (dd, $1 \mathrm{H}, J_{\text {lax, 1eq }} 11.7 \mathrm{~Hz}, J_{\text {leq, } 2} 4.3 \mathrm{~Hz}, \mathrm{H}-1$ eq), 2.27 (dd, $1 \mathrm{H}, J_{1 \mathrm{ax}, 2} 10.0$ $\mathrm{Hz}, \mathrm{H}-1 \mathrm{ax}), 0.96$ (d, 3H, H-6); cluster of signals for both diastereoisomers: $\delta$ 7.43-7.08 (m, $30 \mathrm{H}, \mathrm{Ar}-\mathrm{H}), 4.75-4.40\left(\mathrm{~m}, 6 \mathrm{H}, 2 \times \mathrm{OCH}_{2} \mathrm{Ph}, 2 \times \mathrm{NCHPh}_{2}\right) ;{ }^{13} \mathrm{C} \mathrm{NMR}\left(\mathrm{CDCl}_{3}, 50.33 \mathrm{MHz}\right)$ compound 6d: $\delta 75.2$ (C-2), 73.9 (C-3), 70.8 (C-4), 56.3 (C-5), 49.1 (C-1), 15.9 (C-6); compound 7d: $\delta 76.9$ (C-2), 73.4 (C-3), 71.9 (C-4), 54.8 (C-5), 45.7 (C-1), 7.6 (C-6); cluster of signals for both diastereoisomers: $\delta$ 143.2, 142.1, 141.5, 138.4, 138.1, 137.7 (6×Ar-C), 129.8-126.6 (Ar-CH), $72.0\left(2 \times \mathrm{OCH}_{2} \mathrm{Ph}\right), 64.7\left(2 \times \mathrm{CHPh}_{2}\right)$. Anal. Calcd for $\mathrm{C}_{26} \mathrm{H}_{29} \mathrm{NO}_{3}$ : C, 77.39; $\mathrm{H}, 7.24$; N, 3.47. Found: C, 77.36; H, 7.27; N, 3.49. 


\subsubsection{2-O-benzyl-N-hydroxy-1,5,6-trideoxy-1,5-imino-D-galactitol (6e).}

To a solution of $5 \alpha, \beta\left(400 \mathrm{mg}, 1.59 \mathrm{mmol}, 40 \mathrm{~mL}\right.$ of dry $\mathrm{MeOH}$ ) a solution of $\mathrm{NH}_{2} \mathrm{OH} \cdot \mathrm{HCl}$ (176 mg, $2.54 \mathrm{mmol}, 30 \mathrm{~mL}$ of dry $\mathrm{MeOH}$ ) and a solution of $\mathrm{NaBH}_{3} \mathrm{CN}$ (199 mg, 3.17 $\mathrm{mmol}, 34 \mathrm{~mL}$ of dry $\mathrm{MeOH}$ ) were added and the reaction was conducted according to the general procedure (Method B). After $26 \mathrm{~h}$, TLC analysis (8:2 EtOAc-MeOH) revealed the complete disappearance of the starting material and the formation of one spot $\left(R_{f} 0.18\right)$. The ${ }^{1} \mathrm{H}$ NMR spectrum of the residue $(426 \mathrm{mg}$ ) showed that the crude was mainly (ca 95\%) constituted by azapyranose $6 \mathrm{e}$ and purification of the crude product by flash chromatography on silica gel (95:5 $\left.\mathrm{EtOAc}-\mathrm{i}-\mathrm{PrOH}+0.1 \% \mathrm{Et}_{3} \mathrm{~N}\right)$ afforded pure $6 \mathrm{e}(224 \mathrm{mg}$, $56 \%$ yield) as a white solid; $\mathrm{R}_{f} 0.23$ (95:5 EtOAc-'PrOH); mp 115-117 ${ }^{\circ} \mathrm{C}$ (chrom); $[\alpha]_{\mathrm{D}}$ +17.8 (c 1.0, $\left.\mathrm{CHCl}_{3}\right) ;{ }^{1} \mathrm{H}$ NMR $\left(\mathrm{CD}_{3} \mathrm{CN}-\mathrm{D}_{2} \mathrm{O}, 200.13 \mathrm{MHz}\right): \delta$ 7.39-7.27 (m, 5H, Ar-H), 4.63 (d, 2H, $\mathrm{CH}_{2} \mathrm{Ph}$ ), 3.68 (m, 1H, H-2, H-4), 3.39 (dd, 1H, J2,3 $9.6 \mathrm{~Hz}, J_{3,4} 3.4 \mathrm{~Hz}, \mathrm{H}-3$ ), 3.44 (dd, 1H, J Jax,1eq $\left.10.4 \mathrm{~Hz}, J_{1 \mathrm{eq}, 2} 4.6 \mathrm{~Hz}, \mathrm{H}-1 \mathrm{eq}\right), 2.43$ (m, 1H, H-5), 2.29 (bdd, 1H, J Jax,2 10.1 $\mathrm{Hz}, \mathrm{H}-1 \mathrm{ax}), 1.13$ (d, 3H, J5,6 $6.4 \mathrm{~Hz}, \mathrm{H}-6) ;{ }^{13} \mathrm{C}$ NMR $\left(\mathrm{CD}_{3} \mathrm{CN}-\mathrm{D}_{2} \mathrm{O}, 50.33 \mathrm{MHz}\right): \delta 139.7$ (ArC), 129.2, 128.8, $128.5(\mathrm{Ar}-\mathrm{CH}), 76.4$ (C-2), 75.4 (C-3), $73.1\left(\mathrm{OCH}_{2} \mathrm{Ph}\right), 73.0(\mathrm{C}-4), 64.9$ (C-5), 61.1 (C-1), 15.7 (C-6); Anal. Calcd for $\mathrm{C}_{13} \mathrm{H}_{19} \mathrm{NO}_{4}$ : C, 61.64; H, 7.56; N, 5.53. Found: C, 61.60; H, 7.51; N, 5.50 .

\subsubsection{2-O-benzyl- $N$-(1'-carbomethoxyethyl)-1,5,6-trideoxy-1,5-imino-D-galactitol (6f) and 2-O-benzydryl-N-(1'-carbomethoxyethyl)-1,5,6-trideoxy-1,5-imino-L-altritol (7f).}

The double reductive amination of $5 \alpha, \beta(500 \mathrm{mg}, 1.98 \mathrm{mmol})$ was performed with Gly$\mathrm{OMe} \cdot \mathrm{HCl}(249 \mathrm{mg}, 1.98 \mathrm{mmol})$ and $\mathrm{NaBH}_{3} \mathrm{CN}(249 \mathrm{mg}, 3.96 \mathrm{mmol})$ following the general procedure (Method B). After $20 \mathrm{~h}$, TLC analysis (EtOAc) showed the complete disappearance of the starting material and the formation of two spots $\left(R_{f} 0.24\right.$ and 0.19$)$. The crude residue $(537 \mathrm{mg})$, analyzed by $\mathrm{NMR}\left(\mathrm{CDCl}_{3}\right)$, showed a mixture of azapyranoses $6 \mathbf{f}$ and $7 \mathbf{f}$ in a 70:30 ratio, measured on the relative intensities of the C-6 signals at $\delta 15.9$ and 10.3 respectively. Purification of the crude product by flash chromatography on silica gel (EtOAc $+0.1 \%$ of $30 \%$ aq $\mathrm{NH}_{3}$ solution) gave pure $\mathbf{6 f}$ (239 $\mathrm{mg}, 39 \%$ yield) and $7 f(104 \mathrm{mg}, 17 \%$ yield).

2-O-benzyl-N-(1'-carbomethoxyethyl)-1,5,6-trideoxy-1,5-imino-D-galactitol

(6f). Clear syrup, $\mathrm{R}_{f} 0.19$ (EtOAc); $[\alpha]_{\mathrm{D}}+31.8\left(c\right.$ 1.0, $\left.\mathrm{CHCl}_{3}\right) ;{ }^{1} \mathrm{H}$ NMR $\left(\mathrm{CD}_{3} \mathrm{CN}-\mathrm{D}_{2} \mathrm{O}, 200.13 \mathrm{MHz}\right): \delta$ 7.36-7.26 (m, 5H, Ar-H), 4.63, 4.57 (AB system, 2H, JA,B $11.8 \mathrm{~Hz}, \mathrm{OCH}_{2} \mathrm{Ph}$ ), 3.62 (s, 3H, OMe), 3.57 (ddd, 1H, J Jax,2 $10.5 \mathrm{~Hz}, J_{2,3} 9.4 \mathrm{~Hz}, J_{1 \mathrm{eq}, 2} 5.0 \mathrm{~Hz}, \mathrm{H}-2$ ), 3.53 (dd, $1 \mathrm{H}, J_{3,4} 3.3$ 
$\mathrm{Hz}, J_{4,5} 1.5 \mathrm{~Hz}, \mathrm{H}-4$ ), 3.39, 3.31 (AB system, 2H, JA,B $17.3 \mathrm{~Hz}, \mathrm{H}-2^{\prime}$ ), 3.30 (dd, 1H, H-3), 3.03 (dd, $1 \mathrm{H}, J_{1 \mathrm{ax}, 1 \mathrm{eq}} 11.1 \mathrm{~Hz}, \mathrm{H}-1 \mathrm{eq}$ ), 2.73 (dq, $1 \mathrm{H}, J_{5,6} 6.6 \mathrm{~Hz}, \mathrm{H}-5$ ), 2.32 (dd, $1 \mathrm{H}, \mathrm{H}-1 \mathrm{ax}$ ), 1.06 (d, 3H, H-6); ${ }^{13} \mathrm{C}$ NMR $\left(\mathrm{CD}_{3} \mathrm{CN}-\mathrm{D}_{2} \mathrm{O}, 50.33 \mathrm{MHz}\right): \delta 173.1(\mathrm{C}=\mathrm{O}), 139.9(\mathrm{Ar}-\mathrm{C}), 129.2$, 128.7, 128.4 (Ar- $\mathrm{CH}$ ), 77.0 (C-2), 76.1 (C-3), 74.3 (C-4), $72.8\left(\mathrm{OCH}_{2} \mathrm{Ph}\right), 57.8$ (C-5), 55.9 (C-2'), 54.2 (C-1), 52.1 (OMe); 16.4 (C-6); Anal. Calcd for $\mathrm{C}_{16} \mathrm{H}_{23} \mathrm{NO}_{5}: \mathrm{C}, 62.12 ; \mathrm{H}, 7.49 ; \mathrm{N}$, 4.53. Found: C, $62.07 ; \mathrm{H}, 7.45 ; \mathrm{N}, 4.51$.

2-O-benzyl-N-(1'-carbomethoxyethyl)-1,5,6-trideoxy-1,5-imino-L-altritol (7f). Clear syrup, $\mathrm{R}_{f}$ 0.24 (EtOAc); $[\alpha]_{\mathrm{D}}+27.8$ (c 1.1, $\left.\mathrm{CHCl}_{3}\right) ;{ }^{1} \mathrm{H} \mathrm{NMR}\left(\mathrm{CD}_{3} \mathrm{CN}-\mathrm{D}_{2} \mathrm{O}, 200.13 \mathrm{MHz}\right): \delta$ 7.36-7.26 (m, $5 \mathrm{H}, \mathrm{Ar}-\mathrm{H}$ ), 4.61, 4.53 (AB system, $2 \mathrm{H}, \mathrm{J}_{\mathrm{A}, \mathrm{B}} 11.9 \mathrm{~Hz}, \mathrm{OCH}_{2} \mathrm{Ph}$ ), 3.63 (s, 3H, OMe), 3.71 (dd, $1 \mathrm{H}, J_{2,3} 6.2 \mathrm{~Hz}, J_{3,4} 3.2 \mathrm{~Hz}, \mathrm{H}-3$ ), 3.58 (ddd, $1 \mathrm{H}, J_{1 \mathrm{ax}, 2} 6.0 \mathrm{~Hz}, J_{1 \mathrm{eq}, 2} 3.5 \mathrm{~Hz}, \mathrm{H}-2$ ), 3.46 (dd, $1 \mathrm{H}, J_{4,5} 6.5 \mathrm{~Hz}, \mathrm{H}-4$ ), 3.39, 3.27 (AB system, 2H, $\mathrm{J}_{\mathrm{A}, \mathrm{B}} 17.1 \mathrm{~Hz}, \mathrm{H}-2$ '); 2.89 (dq, $1 \mathrm{H}, J_{5,6}$ 6.7 Hz, H-5), 2.84 (dd, 1H, J Jax,1eq $12.2 \mathrm{~Hz}, \mathrm{H}-1 \mathrm{eq}$ ), 2.57 (dd, 1H, H-1ax), 1.00 (d, 3H, H-6); ${ }^{13} \mathrm{C}$ NMR $\left(\mathrm{CD}_{3} \mathrm{CN}-\mathrm{D}_{2} \mathrm{O}, 50.33 \mathrm{MHz}\right): \delta 172.6(\mathrm{C}=\mathrm{O}), 140.0(\mathrm{Ar}-\mathrm{C}), 129.2,128.6,128.3(\mathrm{Ar}-$ $\mathrm{CH}), 77.4$ (C-2), 73.2 (C-3), $71.8\left(\mathrm{OCH}_{2} \mathrm{Ph}\right), 70.7$ (C-4), 55.1 (C-2'), 57.1 (C-5), 51.8 (OMe), 50.2 (C-1), 13.1 (C-6). Anal. Calcd for $\mathrm{C}_{16} \mathrm{H}_{23} \mathrm{NO}_{5}$ : C, 62.12; H, 7.49; N, 4.53. Found: C, 62.08; $\mathrm{H}, 7.52 ; \mathrm{N}, 4.56$.

\subsubsection{2-O-benzyl- $N$-[(2'R)-1'-carbomethoxy-2'-benzylethyl]-1,5,6-trideoxy-1,5-imino- D-galactitol (6g) and 2-O-benzydryl- $N$-[(2'R)-1'-carbomethoxy-2'-benzylethyl]-1,5,6- trideoxy-1,5-imino-L-altritol (7g).}

A solution of $5 \alpha, \beta(500 \mathrm{mg}, 1.98 \mathrm{mmol}$ ) was treated with D-Phe-OMe. $\mathrm{HCl}$ (427 mg, 1.98 $\mathrm{mmol}$ ) and $\mathrm{NaBH}_{3} \mathrm{CN}(249 \mathrm{mg}, 3.96 \mathrm{mmol}$ ) according to the general procedure (Method $\mathrm{B})$. The reaction was complete in $24 \mathrm{~h}$ and TLC analysis (3:7 hexane-EtOAc) revealed the complete disappearance of the starting material and the formation of two spots $\left(R_{f} 0.28\right.$ and 0.16). NMR analysis of the crude product $(756 \mathrm{mg})$ showed a mixture of azapyranoses $\mathbf{6 g}$ and $\mathbf{7 g}$ in a 25:75 ratio estimated on the relative intensities of the C-6 signals at $\delta 16.7$ and 7.1 respectively. Purification of the crude product by flash chromatography on silica gel (1:1 hexane-EtOAc $\left.+0.1 \% \mathrm{Et}_{3} \mathrm{~N}\right)$ gave pure $6 \mathrm{~g}(110 \mathrm{mg}$, $14 \%$ yield) and $7 \mathrm{~g}$ (389 $\mathrm{mg}, 49 \%$ yield).

2-O-benzyl-N-[(2'R)-1'-carbomethoxy-2'-benzylethyl]-1,5,6-trideoxy-1,5-imino-D-galactitol

(6g). Clear syrup; $\mathrm{R}_{f} 0.16$ (3:7 hexane-EtOAc); $[\alpha]_{D}+37.7$ (c 1.1, $\left.\mathrm{CHCl}_{3}\right) ;{ }^{1} \mathrm{H}$ NMR $\left(\mathrm{CD}_{3} \mathrm{CN}-\mathrm{D}_{2} \mathrm{O}, 200.13 \mathrm{MHz}\right)$ : $\delta$ 7.40-7.19 (m, 10H, Ar-H), $4.64\left(\mathrm{~s}, 2 \mathrm{H}, \mathrm{OCH}_{2} \mathrm{Ph}\right), 3.74$ (dd, $\left.1 \mathrm{H}, J_{2^{\prime}, \mathrm{a}} 5.1 \mathrm{~Hz}, J_{2^{\prime}, \mathrm{b}} 9.4 \mathrm{~Hz}, \mathrm{H}-2^{\prime}\right), 3.56$ (s, 3H, OMe), 3.51 (dd, $1 \mathrm{H}, J_{3,4} 3.4 \mathrm{~Hz}, J_{4,5} 1.4 \mathrm{~Hz}$, 
H-4), 3.49 (ddd, $1 \mathrm{H}, J_{1 \mathrm{ax}, 2} 9.8 \mathrm{~Hz}, J_{2,3} 8.8 \mathrm{~Hz}, J_{1 \mathrm{eq}, 2} 4.9 \mathrm{~Hz}, \mathrm{H}-2$ ), 3.30 (dd, $1 \mathrm{H}, \mathrm{H}-3$ ), 3.29 (dd, $1 \mathrm{H}, J_{\text {lax,1eq }} 11.3 \mathrm{~Hz}, \mathrm{H}-1 \mathrm{eq}$ ), 3.00 (dd, $1 \mathrm{H}, \mathrm{J}_{\mathrm{a}, \mathrm{b}} 13.4 \mathrm{~Hz}, \mathrm{CH}_{\mathrm{b}} \mathrm{Ph}$ ), 2.83 (dd, $1 \mathrm{H}, \mathrm{CH}_{\mathrm{a}^{-}}$ $\mathrm{Ph}$ ), 2.65 (dq, 1H, J5,6 $6.6 \mathrm{~Hz}, \mathrm{H}-5$ ), 2.26 (dd, 1H, H-1ax), 1.13 (d, 3H, H-6); ${ }^{13} \mathrm{C} N M R$ $\left(\mathrm{CD}_{3} \mathrm{CN}-\mathrm{D}_{2} \mathrm{O}, 50.33 \mathrm{MHz}\right): \delta 173.6(\mathrm{C}=\mathrm{O}), 140.0,139.8(2 \times \mathrm{Ar}-\mathrm{C}), 130.1-127.2(\mathrm{Ar}-\mathrm{CH})$, 77.6 (C-2), 76.3 (C-3), 74.6 (C-4), $72.6\left(\mathrm{OCH}_{2} \mathrm{Ph}\right), 64.0$ (C-2'), 57.6 (C-5), $52.3(\mathrm{OMe})$, 50.6 (C-1), $31.8\left(\mathrm{NCH}_{2} \mathrm{Ph}\right), 16.7$ (C-6). Anal. Calcd for $\mathrm{C}_{23} \mathrm{H}_{29} \mathrm{NO}_{5}$ : C, 69.15; H, 7.32; N, 3.51. Found: C, $69.11 ; \mathrm{H}, 7.30 ; \mathrm{N}, 3.54$.

2-O-benzyl-N-[(2'R)-1'-carbomethoxy-2'-benzylethyl]-1,5,6-trideoxy-1,5-imino-L-altritol

(7g). Clear syrup; $\mathrm{R}_{f} 0.28$ (3:7 hexane-EtOAc); $[\alpha]_{D}+70.7$ (c 1.2, $\left.\mathrm{CHCl}_{3}\right)$. ${ }^{1} \mathrm{H}$ NMR $\left(\mathrm{CD}_{3} \mathrm{CN}-\mathrm{D}_{2} \mathrm{O}, 200.13 \mathrm{MHz}\right.$ ): $\delta$ 7.38-7.16 (m, 10H, Ar-H), 4.63, 4.54 (AB system, 2H, JA,B $11.9 \mathrm{~Hz}, \mathrm{OCH}_{2} \mathrm{Ph}$ ), 3.81 (dd, $1 \mathrm{H}, \mathrm{J}_{2^{\prime}, \mathrm{a}} 7.2 \mathrm{~Hz}, \mathrm{~J}_{2^{\prime}, \mathrm{b}} 7.7 \mathrm{~Hz}, \mathrm{H}-2^{\prime}$ ), 3.78 (dd, $1 \mathrm{H}, J_{4,5} 6.0 \mathrm{~Hz}$, $J_{3,4} 3.1 \mathrm{~Hz}, \mathrm{H}-4$ ), 3.58 (s, 3H, OMe), 3.52 (ddd, $1 \mathrm{H}, J_{2,3} 7.9 \mathrm{~Hz}, J_{1 \mathrm{ax}, 2} 4.6 \mathrm{~Hz}, J_{1 \mathrm{eq}, 2} 3.0 \mathrm{~Hz}$, $\mathrm{H}-2$ ), 3.27 (dd, $1 \mathrm{H}, \mathrm{H}-3$ ), 3.05 (dd, $1 \mathrm{H}, J_{a, b} 13.6 \mathrm{~Hz}, \mathrm{CH}_{b}-\mathrm{Ph}$ ), 2.99 (dd, $1 \mathrm{H}, J_{1 \mathrm{ax}, 1 \text { eq }} 12.7 \mathrm{~Hz}$, $\mathrm{H}-1$ eq), 2.85 (dd, 1H, CHa-Ph), 2.78 (dq, 1H, $J_{5,6} 6.4 \mathrm{~Hz}, \mathrm{H}-5$ ), 2.73 (dd, 1H, H-1ax), 1.01 (d, 3H, H-6); ${ }^{13} \mathrm{C} N M R\left(\mathrm{CD}_{3} \mathrm{CN}-\mathrm{D}_{2} \mathrm{O}, 50.33 \mathrm{MHz}\right): \delta 173.3(\mathrm{C}=\mathrm{O}), 139.9,139.8(2 \times \mathrm{Ar}-\mathrm{C})$, 130.3-127.1 (Ar- $\mathrm{CH}), 77.5$ (C-2), $73.2(\mathrm{C}-3), 71.8\left(\mathrm{OCH}_{2} \mathrm{Ph}\right), 70.5$ (C-4), $64.2(\mathrm{C}-2$ '), 56.7 (C-5), $51.6(\mathrm{OMe}), 45.1(\mathrm{C}-1), 36.8\left(\mathrm{NCH}_{2} \mathrm{Ph}\right), 7.1$ (C-6). Anal. Calcd for $\mathrm{C}_{23} \mathrm{H}_{29} \mathrm{NO}_{5}$ : C, 69.15; H, 7.32; N, 3.51. Found: C, 69.12; H, 7.29; N, 3.48.

\subsubsection{2-O-benzyl- $N-[(2 ' S)-1$ '-carbomethoxy-2'-benzylethyl]-1,5,6-trideoxy-1,5-imino- D-galactitol (6h) and 2-O-benzydryl- $N$-[(2'S)-1'-carbomethoxy-2'-benzylethyl]-1,5,6- trideoxy-1,5-imino-L-altritol (7h).}

A solution of $5 \alpha, \beta(400 \mathrm{mg}, 1.59 \mathrm{mmol})$ was treated with L-Phe-OMe.HCl (342 $\mathrm{mg}, 1.59$ $\mathrm{mmol}$ ) and $\mathrm{NaBH}_{3} \mathrm{CN}$ (199 mg, $3.17 \mathrm{mmol}$ ) and the reaction was performed according to the general procedure (Method B). After $24 \mathrm{~h}$, TLC analysis (2:8 hexane-EtOAc) showed the complete disappearance of the starting material and the formation of one spot $\left(R_{f}\right.$ 0.39). The NMR spectrum of residue $(665 \mathrm{mg})$ showed a mixture of azapyranoses $6 \mathrm{~h}$ and $7 \mathrm{~h}$ in a 65:35 ratio measured on the relative intensities of the C- 6 signals at $\delta 16.3$ and 11.5 respectively. Several attempts to separate the components of the mixture through TLC gave negative result. Purification of the crude product by flash chromatography on silica gel $\left(98: 2 \mathrm{CHCl}_{3}{ }^{-} \mathrm{PrOH}+0.1 \% \mathrm{Et}_{3} \mathrm{~N}\right)$ gave a mixture of pure $6 \mathbf{h}$ and $\mathbf{7 h}(370 \mathrm{mg}$, $58 \%$ yield) as a clear syrup; $\mathrm{R}_{f} 0.39$ (2:8 hexane-EtOAc); ${ }^{1} \mathrm{H}$ NMR $\left(\mathrm{CD}_{3} \mathrm{CN}, 200.13 \mathrm{MHz}\right.$,): Compound 6h: $\delta$ 4.68, 4.57 (AB system, $2 \mathrm{H}, \mathrm{J}_{\mathrm{A}, \mathrm{B}} 12.2 \mathrm{~Hz}, \mathrm{OCH}_{2} \mathrm{Ph}$ ), 3.70 (dd, $1 \mathrm{H}, \mathrm{J}_{2^{\prime}, \mathrm{a}} 6.3$ $\mathrm{Hz}, \mathrm{J}_{2, \mathrm{~b}} 9.7 \mathrm{~Hz}, \mathrm{H}-2^{\prime}$ ), 3.64 (s, 3H, OMe), 3.50 (dd, 1H, $J_{2,3} 8.3 \mathrm{~Hz}, J_{3,4} 3.1 \mathrm{~Hz}, \mathrm{H}-3$ ), 3.35 
(ddd, 1H, J Jax,2 $9.2 \mathrm{~Hz}, J_{1 \mathrm{eq}, 2} 4.1 \mathrm{~Hz}, \mathrm{H}-2$ ), 3.32 (dd, $1 \mathrm{H}, J_{4,5} 1.0 \mathrm{~Hz}, \mathrm{H}-4$ ), 3.24 (dd, $1 \mathrm{H}$, $J_{\text {lax, } 1 \text { eq }} 12.4 \mathrm{~Hz}, \mathrm{H}-1$ eq), 2.75 (dd, $1 \mathrm{H}, J_{\mathrm{a}, \mathrm{b}} 13.7 \mathrm{~Hz}, \mathrm{CH}_{b}-\mathrm{Ph}$ ), 2.70 (dd, $1 \mathrm{H}, \mathrm{CH}_{\mathrm{a}}-\mathrm{Ph}$ ), 2.64 (dq, 1H, J5,6 6.4 Hz, H-5), 2.56 (dd, 1H, H-1ax), 0.93 (d, 3H, H-6); compound 7h: $\delta$ 4.70, 4.56 (AB system, 2H, $\mathrm{J}_{\mathrm{A}, \mathrm{B}} 12.0 \mathrm{~Hz}, \mathrm{OCH}_{2} \mathrm{Ph}$ ), 3.61 (dd, $1 \mathrm{H}, \mathrm{J}_{2^{\prime}, \mathrm{a}} 4.6 \mathrm{~Hz}, \mathrm{~J}_{2^{\prime}, \mathrm{b}} 8.4 \mathrm{~Hz}, \mathrm{H}-2^{\prime}$ ), 3.60 (dd, $1 \mathrm{H}, \mathrm{J}_{\mathrm{a}, \mathrm{b}} 13.4 \mathrm{~Hz}, \mathrm{CH}_{\mathrm{b}} \mathrm{Ph}$ ), 3.53 (s, 3H, OMe), 3.12 (dd, $1 \mathrm{H}, \mathrm{CH}_{a}-\mathrm{Ph}$ ); 3.25 (m, $4 \mathrm{H}, \mathrm{H}-1$ eq, H-2, H-3, H-4), 2.88 (bq, $1 \mathrm{H}, J_{5,6} 6.8 \mathrm{~Hz}, \mathrm{H}-5$ ), 1.83 (dd, $1 \mathrm{H}, J_{1 \text { ax, } 1 \text { eq }} 11.3 \mathrm{~Hz}$, $\left.J_{1 a x, 2} 4.8 \mathrm{~Hz}, \mathrm{H}-1 \mathrm{ax}\right), 0.97$ (d, 3H, H-6); cluster of signals for both diastereoisomers: $\delta$ 7.447.08 (m, 20H, Ar-H); ${ }^{13} \mathrm{C} \mathrm{NMR} \mathrm{(} \mathrm{CD}_{3} \mathrm{CN}, 50.33 \mathrm{MHz}$ ): compound 6h: $\delta 172.8(\mathrm{C}=\mathrm{O}), 140.1$, 139.8 (2×Ar-C), 77.2 (C-2), 76.7 (C-3), 74.9 (C-4), $72.8\left(\mathrm{OCH}_{2} \mathrm{Ph}\right), 61.0$ (C-2'), 58.6 (C-5), 51.8 (OMe), 49.1 (C-1), $36.0\left(\mathrm{NCH}_{2} \mathrm{Ph}\right), 16.3$ (C-6); compound 7h: $\delta 174.3(\mathrm{C}=\mathrm{O}), 140.0$, 139.4 (2×Ar-C), 77.5 (C-2), 74.1 (C-3), $72.3\left(\mathrm{OCH}_{2} \mathrm{Ph}\right), 71.9$ (C-4), 66.9 (C-2'), 61.3 (C-5), $52.0(\mathrm{OMe}), 43.0(\mathrm{C}-1), 36.2\left(\mathrm{NCH}_{2} \mathrm{Ph}\right), 11.5(\mathrm{C}-6)$; cluster of signals for both diastereoisomers: $\delta$ 129.9-127.1 (Ar- $\mathrm{CH}$ ). Anal. Calcd for $\mathrm{C}_{23} \mathrm{H}_{29} \mathrm{NO}_{5}$ : C, 69.15; H, 7.32; N, 3.51. Found: C, $69.17 ; \mathrm{H}, 7.35 ; \mathrm{N}, 3.53$.

\subsubsection{3,4-di-O-Acetyl-2-O-benzyl- $N$-benzyl-1,5,6-trideoxy-1,5-imino-D-galactitol (8).}

Routine acetylation of $6 \mathrm{c}(104 \mathrm{mg}, 0.32 \mathrm{mmol})$ and purification of the crude product by flash chromatography on silica gel (4:6 hexane-EtOAc $\left.+0.1 \% \mathrm{Et}_{3} \mathrm{~N}\right)$ gave pure $8(104 \mathrm{mg}$, $79 \%$ yield) as a clear syrup; $\mathrm{R}_{f} 0.42\left(4: 6\right.$ hexane-EtOAc); $[\alpha]_{D}=+7.1$ (c $\left.0.80, \mathrm{CHCl}_{3}\right) ;{ }^{1} \mathrm{H}$ $\operatorname{NMR}\left(\mathrm{CD}_{3} \mathrm{CN}, 200.13 \mathrm{MHz}\right.$ ): $\delta$ 7.38-7.19 (m, 10H, Ar-H), 5.25 (dd, $1 \mathrm{H}, J_{3,4} 3.6 \mathrm{~Hz}, \mathrm{~J}_{4,5} 2.1$ $\mathrm{Hz}, \mathrm{H}-4$ ), 4.76 (dd, $1 \mathrm{H}, J_{2,3} 9.6 \mathrm{~Hz}, \mathrm{H}-3$ ), 4.48 (s, 2H, OCH $\mathrm{O}_{2} \mathrm{Ph}$ ), 3.83, 3.27 (sistema AB, $2 \mathrm{H}, J_{\mathrm{A}, \mathrm{B}} 13.7 \mathrm{~Hz}, \mathrm{NCH}_{2} \mathrm{Ph}$ ), 3.73 (ddd, $1 \mathrm{H}, J_{1 \mathrm{ax}, 2} 9.6 \mathrm{~Hz}, J_{1 \text { eq, } 2} 4.7 \mathrm{~Hz}, \mathrm{H}-2$ ), 3.04 (dd, $1 \mathrm{H}$, $\left.J_{\text {lax, 1eq }} 11.7 \mathrm{~Hz}, \mathrm{H}-1 \mathrm{eq}\right), 2.71$ (dq, $1 \mathrm{H}, J_{5,6} 6.5 \mathrm{~Hz}, \mathrm{H}-5$ ), 2.08, 1.93 (2s, each $3 \mathrm{H}$, $2 \times \mathrm{CH}_{3} \mathrm{CO}$ ), 2.01 (dd, $\left.1 \mathrm{H}, \mathrm{H}-1 \mathrm{ax}\right), 1.13$ (d, 3H, H-6); ${ }^{13} \mathrm{C} \mathrm{NMR}\left(\mathrm{CD}_{3} \mathrm{CN}, 50.33 \mathrm{MHz}\right): \delta$ 171.2, $171.1(2 \times \mathrm{C}=\mathrm{O}), 139.8,139.7(2 \times \mathrm{Ar}-\mathrm{C}), 129.8-127.9(\mathrm{Ar}-\mathrm{CH}), 75.7$ (C-2), $74.0(\mathrm{C}-3)$, $73.2(\mathrm{C}-4), 72.8\left(\mathrm{OCH}_{2} \mathrm{Ph}\right), 57.7(\mathrm{C}-5), 57.1\left(\mathrm{NCH}_{2} \mathrm{Ph}\right), 54.6$ (C-1), 21.0, $20.9\left(2 \times \mathrm{CH}_{3} \mathrm{CO}\right)$, 15.9 (C-6). Anal. Calcd for $\mathrm{C}_{24} \mathrm{H}_{29} \mathrm{NO}_{5}$ : C, 70.05; H, 7.10; N, 3.40. Found: C, 69.98; $\mathrm{H}$, $7.06 ; \mathrm{N}, 3.36$.

\subsubsection{3,4-di-O-Acetyl-2-O-benzyl- N-benzyl-1,5,6-trideoxy-1,5-imino-L- altritol (9).}

Routine acetylation of $7 \mathrm{c}(94 \mathrm{mg}, 0.29 \mathrm{mmol})$ and purification of the crude product by flash chromatography on silica gel (4:6 hexane-EtOAc $\left.+0.1 \% \mathrm{Et}_{3} \mathrm{~N}\right)$ gave pure $9(95 \mathrm{mg}, 77 \%$ yield) as a clear syrup; $\mathrm{R}_{f} 0.50$ (4:6 hexane-EtOAc); $[\alpha]_{D}=+32.5$ (c $\left.0.75, \mathrm{CHCl}_{3}\right) ;{ }^{1} \mathrm{H}$ NMR $\left(\mathrm{CD}_{3} \mathrm{CN}, 200.13 \mathrm{MHz}\right.$ ): 7.38-7.23 (m, 10H, Ar-H), 5.10 (dd, $1 \mathrm{H}, J_{2,3} 7.5 \mathrm{~Hz}, J_{3,4} 3.4 \mathrm{~Hz}, \mathrm{H}-$ 3), 3.95 (dd, $1 \mathrm{H}, J_{4,5} 5.2 \mathrm{~Hz}, \mathrm{H}-4$ ), 4.74 (ddd, $1 \mathrm{H}, J_{1 \mathrm{ax}, 2} 6.7 \mathrm{~Hz}, J_{1 \mathrm{eq}, 2} 4.9 \mathrm{~Hz}, \mathrm{H}-2$ ), 4.51 , 
4.43 (AB system, $2 \mathrm{H}, J_{\mathrm{A}, \mathrm{B}} 11.8 \mathrm{~Hz}, \mathrm{OCH}_{2} \mathrm{Ph}$ ), 3.85, 3.49 (AB system, $2 \mathrm{H}, \mathrm{J}_{\mathrm{A}, \mathrm{B}} 13.8 \mathrm{~Hz}$, $\mathrm{NCH}_{2} \mathrm{Ph}$ ), $2.93\left(\mathrm{dq}, 1 \mathrm{H}, J_{5,6} 6.7 \mathrm{~Hz}, \mathrm{H}-5\right), 2.75$ (dd, 1H, J $J_{1 \mathrm{ax}, 1 \text { eq }} 12.4 \mathrm{~Hz}, \mathrm{H}-1 \mathrm{eq}$ ), 2.67 (dd, $1 \mathrm{H}, \mathrm{H}-1 \mathrm{ax}), 2.03,1.99$ (2s, each $\left.3 \mathrm{H}, 2 \times \mathrm{CH}_{3} \mathrm{CO}\right), 1.01$ (d, 3H, $\left.\mathrm{H}-6\right) ;{ }^{13} \mathrm{C}$ NMR $\left(\mathrm{CD}_{3} \mathrm{CN}\right.$, $50.33 \mathrm{MHz}): \delta 171.1(2 \times \mathrm{C}=\mathrm{O}), 140.4,139.6(2 \times \mathrm{Ar}-\mathrm{C}), 129.8-127.9(\mathrm{Ar}-\mathrm{CH}), 74.5(\mathrm{C}-2)$, 73.8 (C-3), $72.2\left(\mathrm{OCH}_{2} \mathrm{Ph}\right), 71.3(\mathrm{C}-4), 58.0\left(\mathrm{NCH}_{2} \mathrm{Ph}\right), 55.9(\mathrm{C}-5), 49.8(\mathrm{C}-1), 21.1$ $\left(2 \times \mathrm{CH}_{3} \mathrm{CO}\right.$ ), 11.3 (C-6). Anal. Calcd for $\mathrm{C}_{24} \mathrm{H}_{29} \mathrm{NO}_{5}: \mathrm{C}, 70.05 ; \mathrm{H}, 7.10 ; \mathrm{N}, 3.40$. Found: $\mathrm{C}$, 69.99; H, 7.07; N, 3.37.

\subsubsection{3,4-di-O-Acetyl-2-O-benzyl- $N$-benzydryl-1,5,6-trideoxy-1,5-imino-D-galactitol} (10) and 3,4-di-O-acetyl-2-O-benzydryl- $\mathrm{N}$-benzydryl-1,5,6-trideoxy-1,5-imino-L-altritol (11).

Routine acetylation of $\mathbf{6 d}$ and $\mathbf{7 d}(45: 55$ mixture, $150 \mathrm{mg}, 0.37 \mathrm{mmol})$ and purification of the crude product by flash chromatography on silica gel (1:9 hexane-EtOAc $\left.+0.1 \% \mathrm{Et}_{3} \mathrm{~N}\right)$ gave pure 10 and 11 (164 mg, 91\% yield) as a 45:55 mixture estimated on the relative intensities of two separated signals (ddd) attributed to $\mathrm{H}-2$ at $\delta 3.61$ and 3.80 respectively. The mixture of title compounds is a clear syrup; $\mathrm{R}_{f} 0.66$ (EtOAc); ${ }^{1} \mathrm{H} \mathrm{NMR}\left(\mathrm{CDCl}_{3}, 200.13\right.$ $\mathrm{MHz}$ ): compound 10: $\delta 5.25$ (bt, $1 \mathrm{H}, J_{4,5}=J_{3,4} 3.4 \mathrm{~Hz}, \mathrm{H}-4$ ), 4.86 (dd, $1 \mathrm{H}, J_{2,3} 7.4 \mathrm{~Hz}, \mathrm{H}-3$ ), 3.61 (ddd, 1H, J Jax,2 $\left.7.4 \mathrm{~Hz}, J_{1 \mathrm{eq}, 2} 3.6 \mathrm{~Hz}, \mathrm{H}-2\right), 2.80$ (m, 2H, H-1eq, H-5), $2.20(\mathrm{~m}, 1 \mathrm{H}, \mathrm{H}-$ 1ax), 1.08 (d, 3H, J5,6 $6.5 \mathrm{~Hz}, \mathrm{H}-6$ ); compound 11: 85.06 (dd, $1 \mathrm{H}, J_{2,3} 10.0 \mathrm{~Hz}, J_{3,4} 3.6 \mathrm{~Hz}$, H-3), 4.99 (dd, 1H, J4,5 $2.4 \mathrm{~Hz}, \mathrm{H}-4$ ), 3.80 (ddd, $1 \mathrm{H}, J_{1 \mathrm{lax}, 2} 10.0 \mathrm{~Hz}, J_{1 \mathrm{eq}, 2} 5.1 \mathrm{~Hz}, \mathrm{H}-2$ ), 3.10 (bq, $1 \mathrm{H}, J_{5,6} 7.0 \mathrm{~Hz}, \mathrm{H}-5$ ), 2.80 (dd, 1H, J $J_{\text {ax, }, 1 \text { eq }} 12.1 \mathrm{~Hz}, \mathrm{H}-1$ eq), 2.35 (dd, $1 \mathrm{H}, \mathrm{H}-1 \mathrm{ax}$ ), 0.96 (d, $3 \mathrm{H}, \mathrm{H}-6)$; clusters of signals for both diastereoisomers $\delta$ 7.44-7.08 $(\mathrm{m}, 2 \times 15 \mathrm{H}, \mathrm{Ar}-\mathrm{H})$, 4.50-4.30 (m, $2 \times 3 \mathrm{H}, \mathrm{OCH}_{2} \mathrm{Ph}, \mathrm{N}-\mathrm{CHPh}$ ), 2.32, 2.16, 1.99, 1.98 (4s, each $\left.3 \mathrm{H}, 4 \times \mathrm{CH}_{3} \mathrm{CO}\right)$; ${ }^{13} \mathrm{C} \mathrm{NMR}\left(\mathrm{CD}_{3} \mathrm{CN}, 50.33 \mathrm{MHz}\right)$ : compound 10: $\delta 74.2$ (C-2), 73.1 (C-3), 71.5 (C-4), 53.1 (C5), 46.9 (C-1), 12.3 (C-6); compound 11: $\delta 73.9$ (C-2), 71.8 (C-3), 70.4 (C-4), 52.7 (C-5), 45.9 (C-1), 8.3 (C-6); clusters of signals for both diastereoisomers $\delta$ 170.3, 170.1, 170.0, $169.9\left(4 \times \mathrm{CH}_{3} \mathrm{CO}\right), 143.2,142.6,142.0,138.6,138.3,138.2(6 \times \mathrm{Ar}-\mathrm{C}), 129.1-125.1$ (Ar$\mathrm{CH}), 72.0,71.7\left(2 \times \mathrm{OCH}_{2} \mathrm{Ph}\right) ; 66.7\left(2 \times \mathrm{NCHPh}_{2}\right), 20.9-20.8\left(4 \times \mathrm{CH}_{3} \mathrm{CO}\right)$. Anal. Calcd for $\mathrm{C}_{30} \mathrm{H}_{33} \mathrm{NO}_{5}$ : C, 73.90; $\mathrm{H}, 6.82 ; \mathrm{N}, 2.87$. Found: $\mathrm{C}, 73.93 ; \mathrm{H}, 6.85 ; \mathrm{N}, 2.90$.

4.2.15. 3,4-di-O-Acetyl-2-O-benzyl- $N$-[(2'S)-1'-carbomethoxy-2'-benzylethyl]-1,5,6trideoxy-1,5-imino-D-galactitol (12) and 3,4-di-O-Acetyl-2-O-benzyl- $N$-[(2'S)-1'carbomethoxy-2'-benzylethyl]-1,5,6-trideoxy-1,5-imino-L-altritol (13). 
Routine acetylation of $6 \mathrm{~h}$ and $7 \mathrm{~h}(65: 35$ mixture, $172 \mathrm{mg}, 0.43 \mathrm{mmol})$, and purification of the crude product by flash chromatography on silica gel $\left(99: 1 \mathrm{CHCl}_{3}-\mathrm{PrOH}+0.1 \% \mathrm{Et}_{3} \mathrm{~N}\right)$ gave pure 12 and 13 (186 mg, 88\% yield) as a 65:55 mixture measured on the relative intensities two separated signals (d) attributed to $\mathrm{H}-6$ at $\delta 0.64$ and 0.83 respectively. The mixture of title compounds is a clear syrup; $\mathrm{R}_{f} 0.38$ (98:2 $\left.\mathrm{CHCl}_{3}{ }^{-} \mathrm{PrOH}\right) ;{ }^{1} \mathrm{H}$ NMR $(1: 1$ $\mathrm{CD}_{3} \mathrm{CN}-\mathrm{C}_{6} \mathrm{D}_{6}, 200.13 \mathrm{MHz}$ ): compound $12 \delta 4.84$ (bt, $\left.1 \mathrm{H}, J_{3,4} 3.7 \mathrm{~Hz} J_{4,5} 1.6 \mathrm{~Hz}, \mathrm{H}-4\right), 4.50$ (dd, $1 \mathrm{H}, J_{2,3} 9.8 \mathrm{~Hz}, \mathrm{H}-3$ ), 4.46, 4.36 (AB system, 2H, $J_{\mathrm{A}, \mathrm{B}} 12.0 \mathrm{~Hz}, \mathrm{OCH}_{2} \mathrm{Ph}$ ), 3.55 (dd, $1 \mathrm{H}$, $J_{2^{\prime}, \mathrm{a}} 6.0 \mathrm{~Hz}, J_{2^{\prime}, \mathrm{b}} 9.6 \mathrm{~Hz}, \mathrm{H}-2^{\prime}$ ), 3.44 (s, 3H, OMe), 3.33 (ddd, 1H, J Jax,2 $10.2 \mathrm{~Hz}, J_{1 \mathrm{eq}, 2} 4.9$ $\mathrm{Hz}, \mathrm{H}-2$ ), 3.16 (dd, $1 \mathrm{H}, J_{\text {lax,1eq }} 11.5 \mathrm{~Hz}, \mathrm{H}-1 \mathrm{eq}$ ), 2.82 (dd, $1 \mathrm{H}, J_{\mathrm{a}, \mathrm{b}} 14.0 \mathrm{~Hz}, \mathrm{CH}_{b}-\mathrm{Ph}$ ), $2.70\left(\mathrm{dq}, 1 \mathrm{H}, \mathrm{J}_{5,6} 6.5 \mathrm{~Hz}, \mathrm{H}-5\right.$ ); 2.64 (dd, 1H, $\mathrm{CH}_{\mathrm{a}} \mathrm{Ph}$ ), 1.91 (dd, 1H, H-1ax), 1.71, 1.65 (2s, each $3 \mathrm{H}, 2 \times \mathrm{CH}_{3} \mathrm{CO}$ ), 0.64 (d, $3 \mathrm{H}, \mathrm{H}-6$ ); compound 13: $\delta 4.78$ (dd, $1 \mathrm{H}, \mathrm{J}_{2,3} 8.7 \mathrm{~Hz}, \mathrm{~J}_{3,4} 3.4$ $\mathrm{Hz}, \mathrm{H}-3), 4.60$ (dd, 1H, J4,5 $3.6 \mathrm{~Hz}, \mathrm{H}-4), 4.43,4.32$ (AB system, 2H, JA,B $11.9 \mathrm{~Hz}$, $\mathrm{OCH}_{2} \mathrm{Ph}$ ), 3.46 (m, $1 \mathrm{H}, \mathrm{H}-2$ '), 3.38 (s, 3H, OMe), 3.26 (ddd, $1 \mathrm{H}, J_{1 \mathrm{ax}, 2} 4.2 \mathrm{~Hz}, J_{\text {leq, } 2} 4.8 \mathrm{~Hz}$, $\mathrm{H}-2$ ), 3.10 (m, 1H, CHb-Ph), 3.05 (dd, $\left.1 \mathrm{H}, J_{1 \mathrm{ax}, 1 \text { eq }} 12.7 \mathrm{~Hz}, \mathrm{H}-1 \mathrm{eq}\right), 2.85$ (bq, 1H, J5,6 6.9 $\mathrm{Hz}, \mathrm{H}-5$ ), 2.76 (dd, 1H, Ja,b $14.2 \mathrm{~Hz}, \mathrm{~J}_{2, \mathrm{a}} 6.9 \mathrm{CH}_{\mathrm{a}} \mathrm{Ph}$ ), 2.70 (dd, 1H, H-1ax), 1.75, 1.60 (2s, each $\left.3 \mathrm{H}, 2 \times \mathrm{CH}_{3} \mathrm{CO}\right), 0.83(\mathrm{~d}, 3 \mathrm{H}, \mathrm{H}-6)$; cluster of signals for both diastereoisomers: $\delta$ 7.38-6.94 (m, 10H, 2xAr-H); ${ }^{13} \mathrm{C}$ NMR $\left(1: 1 \mathrm{CD}_{3} \mathrm{CN}_{-} \mathrm{C}_{6} \mathrm{D}_{6}, 50.33 \mathrm{MHz}\right)$ : Compound 12: $\delta$ 172.8, $170.9(2 \times \mathrm{C}=\mathrm{O}), 75.8$ (C-2), $74.2(\mathrm{C}-3), 73.0(\mathrm{C}-4), 72.8\left(\mathrm{OCH}_{2} \mathrm{Ph}\right), 61.4(\mathrm{C}-2 \mathrm{\prime}), 56.5$ (C-5), 51.7 (OMe), 49.2 (C-1), $35.8\left(\mathrm{NCH}_{2} \mathrm{Ph}\right), 15.7$ (C-6); compound 13: $\delta$ 174.5, 171.0 (2×C=O), 74.5 (C-2), 73.6 (C-3), $72.3\left(\mathrm{OCH}_{2} \mathrm{Ph}\right), 71.9$ (C-4), 66.5 (C-2'), 58.5 (C-5), 52.0 (OMe), $43.8(\mathrm{C}-1), 36.1\left(\mathrm{NCH}_{2} \mathrm{Ph}\right), 11.8(\mathrm{C}-6)$; cluster of signals for both diastereoisomers: $\delta$ 139.7-139.3 (Ar-C), 130.3-126.9 (Ar- $\mathrm{CH}), 21.1-20.7\left(\mathrm{CH}_{3} \mathrm{CO}\right)$. Anal. Calcd for $\mathrm{C}_{27} \mathrm{H}_{33} \mathrm{NO}_{7}$ : C, 67.06; $\mathrm{H}, 6.88 ; \mathrm{N}, 2.90$. Found: $\mathrm{C}, 67.10 ; \mathrm{H}, 6.91 ; \mathrm{N}, 2.88$.

\subsubsection{1,5,6-trideoxy-1,5-imino-D-galactitol hydrochloride (14).}

A solution of $6 \mathrm{c}(393 \mathrm{mg}, 1.2 \mathrm{mmol})$ in $\mathrm{MeOH}(15.0 \mathrm{~mL})$ was treated with $1 \%$ methanolic $\mathrm{HCl}(\mathrm{pH} 2)$ and $10 \% \mathrm{Pd}$ on charcoal $(125 \mathrm{mg})$. The suspension was stirred at room temperature under an $\mathrm{H}_{2}$ atmosphere until TLC analysis (7:3 EtOAc-MeOH) showed the complete disappearance of the starting material $(24 \mathrm{~h})$. The mixture was filtered over Celite, washed with $\mathrm{MeOH}$ and the solution concentrated under diminished pressure to give a crude solid (209 $\mathrm{mg}, 95 \%$ ) constituted (NMR) exclusively by 14 . Trituration of the crude residue with $\mathrm{EtOH}$ afforded pure 14 as a white foam; $[\alpha]_{D}+29.8$ (c 0.9, MeOH); lit. [36] $[\alpha]_{D}+31\left(c\right.$ 1.0, MeOH); NMR data $\left({ }^{1} \mathrm{H}\right.$ and $\left.{ }^{13} \mathrm{C}\right)$ agreed with those reported in the literature [36]. 


\subsubsection{1,5,6-trideoxy-1,5-imino-L-altritol hydrochloride (15).}

A sample of 7c (250 $\mathrm{mg}, 0.76 \mathrm{mmol})$ was treated under the same conditions described above for 14, giving a crude solid (136 mg, 97\%) constituted (NMR) exclusively by the title compound. Trituration of crude residue $(\mathrm{EtOH})$ afforded 15 as a white foam; $[\alpha]_{\mathrm{D}}-8.8(\mathrm{c}$

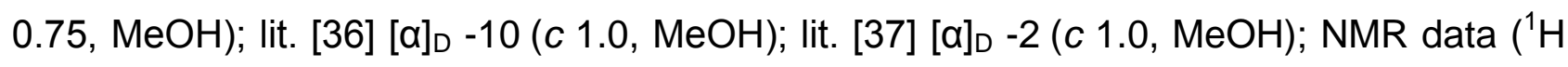
and ${ }^{13} \mathrm{C}$ ) agreed with those reported in the literature $[36,37]$.

\section{Acknowledgements}

The authors would like to thank Professor Giorgio Catelani who inspired the whole project and undergraduate Laura Rosi (University of Pisa) for the contribution to the synthesis of compounds $\mathbf{7 g}$ and 14. This work was supported by funding from "Fondi di AteneoUniversity of Pisa" year 2017 (to F.D. and L.G.).

\section{References}

[1] Gabius, H.-J.; Roth, J. Hisochem Cell. Biol., 2017, 147, 111-117.

[2] Ahmadipour, S.; Beswick, L.; Miller, G.J. Carbohydr. Res., 2018, 469, 38-47.

[3] Hansen, S.U.; Miller, G.J.; Cliff, M.J., Jason, G.C.; Gardiner, J.M. Chem. Sci., 2015, 6, 6158-6164.

[4] Guazzelli, L.; Ulc, R.; Rydner, L.; Oscarson, S. Org. Biomol. Chem., 2015, 13, 65986610.

[5] Guazzelli, L.; McCabe, O.; Oscarson, S. Carbohydr. Res., 2016, 433, 5-13.

[6] Tanphaichitr, N.; Kongmanas, K.; Faull, K.F.; Whitelegge, J.; Compostella, F.; GotoInoue, N.; Linton, J.-J.; Doyle, B.; Oko, R.; Xu, H.; Panza, L.; Saewu, A. Prod. Lipid. Res., 2018, 72, 18-41.

[7] Barnes, D.D.; Lundahl, M.L.E.; Lavelle, E.C.; Scanlan, E.M. ACS Chem. Biol., 2017, 12, 1969-1979.

[8] Podilapu, A.R.; Emmadi, M.; Kulkarni, S.S. Eur. J. Org. Chem, 2018, 3230-3235.

[9] Compain, P.; Martin, O.R.; Eds. Iminosugars: From Synthesis to Therapeutic Applications; Wiley-VCH: Weinheim, Germany, 2007. doi:10.1002/9780470517437.

[10] Bojarová, P.; Kren, V. Trends Biotechnol., 2009, 27, 199-209.

[11] Horne, G.; Wilson, F.X.; Tinsley, J.; Williams, D.H.; Storer, R. Drug Discov. Today 2011, 16, 107-18.

[12] Wadood, A.; Ghufran, M.; Khan, A.; Azam, S.S.; Jelani, M.; Uddin, R. Int. J. Biol. Macromol. 2018, 111, 82-91. 
[13] Junge, B.; Matzke, M.; Stoltefuss, J. Chemistry and structure-activity relationships of glucosidase inhibitors. In: Kuhlmann, J.; Puls, W. Eds. in Handbook of Experimental Pharmacolog: Oral Antidiabetics. Berlin: Springer, 1996, Vol. 119, pp 541-545.

[14] Campbell, L.K.; Baker, D.E.; Campbell, R.K. Ann. Pharmacother. 2000, 34, 12911301.

[15] Lee, A.; Patrick, P.; Wishart, J.; Horo-witz, M.; Morley, J.E. Diabetes Obes. Metab. 2002, 4, 329-335.

[16] Kaku, K. Expert Opin. Pharmacother. 2014, 15, 1181-90.

[17] Giraldo, P.; Andrade-Campos, M.; Alfonso, P.; Irun, P.; Atutxa, K.; Acedo, A.; Barez, A.; Blanes, M.; Diaz-Morant, V.; Fernández-Galán, M.A.; Franco, R.; Gil-Cortes, C.; Giner, V.; Ibañez, A.; Latre, P.; Loyola, I.; Luño, E.; Hernández-Martin, R.; MedranoEngay, B.; Puerta, J.; Roig, I.; de la Serna, J.; Salamero, O.; Villalón, L.; Pocovi, M. Blood Cells Mol. Dis. 2018, 68, 173-179.

[18] Esposito, S.; Principi, N. Expert Rev. Respir. Med. 2016, 10, 79-87.

[19] Ghisaidoobe, A.; Bikker, P.; de Bruijn, A.C.J.; Godschalk, F.D.; Rogaar, E.; Guijt, M.C.; Hagens, P.; Halma, J.M.; van't Hart, S.M.; Luitjens, S.B.; van Rixel, V.H.S.; Wijzenbroek, M.; Zweegers, T.; Donker-Koopman, W.E.; Strijland, A.; Boot, R.; van der Marel, G.; Overkleeft, H.S.; Aerts, J.M.F.G.; van der Berg, R.J.B.H.N. ACS Med. Chem. Lett. 2011, 2, 119-123.

[20] Arora, I.; Kashyap, V.K.; Singh, A.K.; Dasgupta, A.; Kumar, B.; Shaw, A.K. Org. Biomol. Chem. 2014, 12, 6855-6868.

[21] Kiappes, J.L.; Hill, M.L.; Alonzi, D.S.; Miller, J.L.; Iwaki, R.; Sayce, A.C.; Caputo. A.T.; Kato, A.; Zitzmann, N. ACS Chem. Biomol. 2018, 13, 60-65.

[22] Horne, G.; Wilson, F.X.; Tinsley, J.; Williams, D.H.; Storer, R. Drug Discovery Today, 2011, 16, 107-118.

[23] Corkran, H.M.; Munneke, S.; Dangerfield, E.M.; Stocker, B.L.; Timmer, M.S.M. J. Org. Chem. 2013, 78, 9791-9802.

[24] Dhavale, D.D.; Markad, S.D.; Karanjule, N.S.; PrakashaReddy, J.B. J Org Chem. 2004, 69, 4760-4766.

[25] McDonnell, C.; Cronin, L.; O’Brien, J.L.; Murphy P.V. J. Org. Chem. 2004, 69, 35653568.

[26] Karjalainen, O.K.; Koskinen, A.M.P. Org. Biomol. Chem. 2011, 9, 1231-1236.

[27] Singh, P.; Manna, S.K.; Panda, G. Tetrahedron 2014, 70, 1363-1374. 
[28] van den Nieuwendijk, A.M.C.H.; van den Berg, R.J.B.H.N.; Ruben, M.; Witte, M.D.; Brussee, J.; Boot, R.G.; van der Marel, G.A.; Aerts, J.M.F.G.; Overkleeft, H.S. Eur. J. Org. Chem. 2012, 3437-3446.

[29] Soler, A.; Garrabou, X.; Hernández, K.; Gutiérrez, M.L.; Busto, E.; Bujons, J.; Parella, T.; Joglar, J.; Clapés, P. Adv. Synth. Catal. 2014, 356, 3007-3024.

[30] Somfai, P.; Marchand, P.; Torsell, S.; Lindström, U.M. Tetrahedron 2003, 59, 12931299.

[31] Bergeron-Brlek, M.; Meanwell, M.; Britton, R. Nat. Commun. 2015, 6, 6903.

[32] Chacko, S.; Ramapanicker, R. J. Org. Chem. 2015, 80, 4776-4782.

[33] Guazzelli, L.; Catelani, G.; D'Andrea, F.; Gragnani T.; Griselli, A. Eur. J. Org. Chem., 2014, 29, 6527-6537.

[34] Bianchini, R.; Rolla, M.; Isaad, J.; Catelani, G.; Guazzelli, L.; Corsi M.; Bonanni, M. Carbohydr. Res. 2012, 356, 104-109.

[35] Pistarà, V.; Corsaro, A.; Rescifina, A.; Catelani, G.; D'Andrea F.; Guazzelli, L. J. Org. Chem., 2013, 78, 9444-9449.

[36] Guazzelli, L.; Catelani G.; D'Andrea, F. Carbohydr. Res. 2010, 345, 369-376.

[37] D'Andrea, F.; Catelani, G.; Pistarà, V.; Guazzelli, L. Beilstein J. Org. Chem., 2016, 12, 2343-2350.

[38] Catelani, G.; Corsaro, A.; D’Andrea, F.; Mariani, M.; Pistarà, V.; Vittorino, E. Carbohydr. Res. 2003, 338, 2349-2358.

[39] Bollit, V.; Mioskovski, C.; Lee, S-G.; Falck, J.R. J. Org. Chem. 1990, 55, 5812-5813.

[40] Stevens, R.V. Acc. Chem. Res. 1984, 17, 289-296.

[41] Baxter, E.W.; Reitz, A.B. J. Org. Chem. 1994, 59, 3175-3185.

[42] Barili, P.L.; Berti, G.; Catelani, G.; D’Andrea, F.; De Rensis, F.; Puccioni, L. Tetrahedron, 1997, 53, 3407-3416.

[43] Steiner, A.J.; Stutz, A.E.; Tarling, C.A.; Withers, S.G.; Wrodnigg T.M. Carbohydr. Res. 2007, 342, 1850-1858.

[44] Jiang, J.; Kallemeijn, W.W.; Wright, D.W.; van den Nieuwendijk, A.M.C.H.; Coco Rohde, V.; Colomina Folch, E.; van den Elst, H.; Florea, B.I.; Scheij, S.; DonkerKoopman, W.E.; Verhoek, M.; Li, N.; Schürmann, M.; Mink, D.; Boot, R.G.; Codée, J.D.C.; van der Marel, G.A.; Davies, G.J.; Aerts, J.M.F.G.; Overkleeft, H.S. Chem. Sci., 2015, 6, 2782-2789.

[45] Streitha, J.; Boirou, A.; Paillauda, J.-L.; Rodriguez-Pereza, E.-M.; Strehlera, C.; Tschamber, T.; Zehnderb, M. Helv. Chim. Acta, 1995, 78, 61-72. 
[46] Kondo, A.; Ando, K. Ishida, H., Kato, I.; Hasegawa, A.; Kiso, M. J. Carbohydr. Chem, 1994, 13, 545-554

[47] Bock, K.; Pedersen, C. Adv. Carbohydr. Chem. Biochem. 1983, 41, 27-66.

[48] Perrin, D.D.; Armarego, W.L.F.; Perrin, D.R. Purification of Laboratory Chemicals; $2^{\text {nd }}$ ed.; Pergamon Press: Oxford, 1980. 